\title{
How teachers design and implement instructional materials to improve classroom practice
}

\author{
Gabriel Travé González ${ }^{1}$ D, Francisco José Pozuelos Estrada² [D, Gabriel (H) Travé GonzáleziD \\ ${ }^{1}$ Universidad de Huelva (Spain) \\ ${ }^{2}$ Universidad de Huelva (Spain) \\ ${ }^{3}$ Centro del Profesorado de Huelva (Spain) \\ trave@ubu.es,pozuelos@ubu.es, todoloves2@,gmail.com
}

Received July, 2017

Accepted September, 2017

Versión en español

\section{Abstract}

Purpose: To explore teachers' opinions about the design and deployment of teaching materials in class, with specific focus on the implications for professional development of self-produced resources.

Design/methodology: A mixed methods research design involving the administration of a questionnaire to a sample of 864 teachers and the implementation of two case studies of nursery teachers using interviews, observations, journals and recordings.

Findings: The results confirm that textbooks are widely used in Schools for Nursery \& Primary Education throughout Andalusia, where they exert a significant influence on classroom practices, even where teachers seek to complement them with more innovative material. Nevertheless, teacher-made material is highly valued by practitioners not only for promoting meaningful learning but also for its role in enhancing professional development, notwithstanding the obstacles and difficulties it frequently implies. 
Practical implications: The results endorse the need to provide support for teaching staff committed to the developing their own materials.

Social implications: The region-wide policy of free textbooks for all schools should be reviewed in the light of the findings of the research.

Originality/value: The research highlights a paradox at the heart of our educational system regarding the use of instructional materials: while the textbook represents the material of choice for the majority of teachers, these same teachers do not consider it the most appropriate for driving improvement in the teaching/learning process.

Keywords: Teacher opinions, Case studies, Textbooks, Teacher-produced materials, Teaching practices

Jel Codes: I21

\section{Introduction}

Research into teachers' attitudes to, and practices using, teaching material (both textbooks and selfmade material) is a growing area of study. Compared with the wealth of studies into other aspects of materials, such as the ideological, epistemological, axiological, psychological and educational, it is somewhat under-represented. (Apple, 1986; Carvalho, Silva \& Ferrero, 2007; Pinto, 2007; Su, 2007; Travé \& Pozuelos, 2008; Atienza \& Van Dijk, 2010; Hernández, 2012).

Teachers' positions on the materials they use have been studied through mixed methodological approaches which gather both quantitative and qualitative data from questionnaires and interviews (Kasim, 2008; Forbes \& Davis, 2010; Peiró-Velert, Molina-Alventosa, Kirk \& Devís-Devís, 2015). These studies represent an initial exploration of teachers' thinking and practice in the classroom, (Pérez Gómez \& Gimeno, 1994; Rodríguez, 2000; López Hernández, 2007), but we must recognise that there is still much to learn.

From a qualitative perspective, case studies provide in-depth knowledge of the classroom and constitute a line of research with growing scientific impact (Area, 1987; Zahorik, 1991; Sosniak \& Stodolsky, 1993; Vargas \& Chavarria, 2011). This methodology allows for the joint analysis of educational materials alongside teachers' corresponding perceptions and practices (Henning, Hlawatsch 
\& Lucken, 2007; Krajcik, Mcneill \& Reiser, 2008; Charalambous \& Hill, 2012; Arias, Bismack, Davis \& Palincsar, 2016; Chong, 2016). Among the findings of these studies, and of particular interest to this paper, is the identification of two broad models regarding the use of materials in class, one in which practitioners show dependence on the textbook, and restrict themselves to a traditional conception of teaching, and another in which the teacher operates with autonomy, and takes a critical and reflective approach (Güemes, 2001). Another study found that teachers taking innovative approaches are more disposed to drawing on a variety of teaching resources and materials, or at least of putting the textbook to a less conventional use (Paredes, 1999).

More recent research has explored other aspects relating to the use of various materials - especially virtual - (Winzenried, Dalgarno \& Tinkler, 2010; Yelas \& Engels, 2010; Figg \& Jaipal-Jamani, 2011; Mckenney \& Voogt, 2012), and the importance of the conceptions and practices of teachers following training courses in both initial and in-service contexts. Among others, these studies drew the following conclusions:

- "all teachers taking part in the study, including those who were not reliant on a single text, used textbooks as their primary reference for planning" (Fernández Reiris, 2003, pp. 609);

- novice teachers spend an inordinate amount of time selecting a textbook, and textbooks possess a significant capacity to alter their conceptions and practices (Grossman \& Thompson, 2008); and

- teaching materials promote learning on the part of the pupils and stimulate teachers' professional development in proportion to the flexibility they offer in terms of adapting to different school contexts and teaching goals, and their potential for updating the topics and pedagogical strategies they employ (Zenobi, 2012).

In our case, we have conducted various studies into the attitudes and practices of teachers regarding, inter alia, enquiry-based teaching materials (Travé, Pozuelos \& Cañal, 2006; Pozuelos, Travé \& Cañal, 2007; Pozuelos, Travé \& Cañal, 2010). Amongst the findings, one of the most striking is the tendency for teachers's conceptions to follow a cline of professional development, from methodologically simple application of the textbook or other pre-prepared material, to more sophisticated approaches which integrate a wide range of self-produced resources structured in accordance with the demands of inquiry-based project work. In this instance, the research project incorporates two complementary elements, the first an extensive, questionnaire-based inquiry, and the second an intensive, teacher- 
focused dual case-study. The mixed methodology of the two perspectives aims to achieve an in-depth understanding of how teachers design and deploy materials in class. Specifically, the research questions focused on three categories:

- What materials are used in class and how are they chosen?

- What role do materials play in relation to actual practice, and how are they produced?

- To what extent do teaching materials constrain methodology?

\section{Design and methodology}

As mentioned above, the study took a mixed methods research design, based on the administration of a questionnaire to a sample of teachers, and the carrying out of two case studies, a design which Loeb, Knapp and Elfers (2008) regard as offering a high degree of complementarity.

Selecting the sample of teachers for completing the questionnaire was carried out by random sampling of towns and cities throughout the eight provinces comprising Andalusia. The selection process was affected to some extent by school size due to the administrative peculiarities of smaller schools and those with incomplete cohorts, but the sample was otherwise random. Once chosen, each school was sent fourteen questionnaires for the head teacher to distribute to those members of staff teaching the Social and Natural Science subjects (two of the five core subjects in the nursery and primary curriculum), in proportion with the numbers of teaching staff at each level. The procedure gathered data from a total of 94 early childhood schools across Andalusia (incorporating nursery (Spanish 'infantil', ages 3-5) and primary (ages 6-11) levels in one centre).

For their part, the case studies were selected as a complementary approach for exploring the use of teaching materials in the classroom. Simons (2009, pp. 3) considers that "The primary purpose for undertaking a case study is to explore the particularity, the uniqueness of the single case". The methodology pertains to the tradition of collaborative action research (McKernan, 1991). The main criteria for selecting the subjects were that those involved should be volunteers, have an active interest in educational innovation, commit themselves for a full academic year, and be open to negotiating the use and publication of the resultant data. 
The two schools that were ultimately chosen from all those that expressed an interest, not only met the above criteria, but had the additional benefit of representing very different educational contexts, suggesting the potential for fruitful comparisons.

\subsection{Research tools}

The main instrument of data gathering was a 51-item questionnaire with a four-point Likert scale for each question. The options ranged from "completely agree" to "completely disagree", with an additional box in which respondents could optionally write any "clarifications or doubts". The questions focused on various aspects of teaching materials, both self-produced resources and commercially available textbooks, and were grouped into the following three categories:

- production and evaluation;

- epistemological, axiological and psychological aspects; and

- pedagogical considerations and conformity to the national curriculum.

For contextual purposes, we included additional questions which gathered demographic, academic and professional information from respondents. The questionnaire was distributed throughout the Autonomous Community of Andalucia (Spain), which at the time had 50,576 teachers registered across the nursery and primary schools under its control, from whom we received a total of 864 completed questionnaires.

Various standard tools (described below) were used in the two case studies for capturing the different aspects of the teachers' duties, and the data these provided were then subjected to detailed analysis.

The case studies featured a series of semi-structured interviews, chosen to allow more in-depth responses, and an additional questionnaire - Questionnaire F - which complemented that used in the quantitative phase, and was aimed at characterising the respondent's teaching of the social and natural science subjects (Travé, Pozuelos, Cañal \& Rodríguez, 2016). Various other teaching-related documents, including teacher diaries and notebooks (field notes), and the researcher's journal, also provided firsthand accounts from direct observation. To these were added video recordings of seven lessons and trips out to local shops and other services. The analysis of all documents relating to the planning and execution of the teaching, conformed to the guidelines provided by Bardin (1996), requiring all 
recorded data to be transcribed and classified. Finally, all data derived from the various data-gathering instruments were put through a process of triangulation (Martínez-Rizo, 2012).

Processing the data from the two case studies required varying techniques and procedures. The data from the initial questionnaire was analysed with the SPSS statistical package (version 16) and the programme SPAD (version 4.5). The results for each question within the various categories were spread across the four options of the Likert scale, whereby answers 1 and 2 indicated complete or partial disagreement, respectively, while answers 3 and 4 indicated complete or partial agreement.

At the same time, the anlaysis of data drawn from the case studies was carried out using a process of categorisation and, due to the size and complexity of the data, were then processed with the ATLAS.ti programme (v6.2). Textual citations were given a numerical code as in the following example:

“The tasks are highly practical and the pupils are more motivated" (4:37, 248:250, Teacher 2)

The coding $<4: 37>$ should be read as < number of source document): citation number within document $>$. Similarly, the second part $<248: 250>$ refers to <line number of commencement: line number of termination $>$ while $<$ Teacher $2>$ simply provides the attribution of the document. The analysis was structured around the three categories pertaining to the research questions, as illustrated in Table 1.

\begin{tabular}{|c|c|c|c|c|}
\hline Categories & Questions & Contents & Objetives & Research instruments \\
\hline $\begin{array}{l}\text { Category } 1 \\
\text { Teaching } \\
\text { materials: } \\
\text { textbook versus } \\
\text { self-produced } \\
\text { material }\end{array}$ & $\begin{array}{l}\text { What materials are } \\
\text { used in class? Why } \\
\text { were the materials } \\
\text { chosen? }\end{array}$ & $\begin{array}{l}\text { Types of teaching } \\
\text { materials in use. } \\
\text { Evaluation of the } \\
\text { textbook and self- } \\
\text { produced materials. } \\
\text { Reasons for choosing the } \\
\text { materials. }\end{array}$ & $\begin{array}{l}\text { To describe the type of } \\
\text { materials used: textbook } \\
\text { versus self-produced } \\
\text { material. } \\
\text { To ascertain teacher } \\
\text { evaluation of different } \\
\text { materials. } \\
\text { To analyse reasons for } \\
\text { selecting materials. }\end{array}$ & \multirow{3}{*}{$\begin{array}{l}\text { Interview } \\
\text { Questionnaire F } \\
\text { Teacher's journal } \\
\text { Researcher's journal } \\
\text { Teacher notebook } \\
\text { Analysis of documents } \\
\text { (Teaching project) } \\
\text { Video recording and } \\
\text { transcription } \\
\text { General questionnaire } \\
\text { (regional sample) }\end{array}$} \\
\hline $\begin{array}{l}\text { Category } 2 \\
\text { Role of } \\
\text { materials in the } \\
\text { learning } \\
\text { process }\end{array}$ & $\begin{array}{l}\text { ¿What role do } \\
\text { materials play } \\
\text { regarding pedagogical } \\
\text { considerations? } \\
\text { ¿How are materials } \\
\text { produced? }\end{array}$ & $\begin{array}{l}\text { Materials and pedagogical } \\
\text { considerations: key } \\
\text { competences, contents, } \\
\text { methodology, activities } \\
\text { and evaluation. } \\
\text { Adapting the textbook. } \\
\text { Planning self-produced } \\
\text { materials. }\end{array}$ & $\begin{array}{l}\text { To describe the role of } \\
\text { materials in relation to the } \\
\text { other pedagogical } \\
\text { considerations. } \\
\text { To gain understanding of } \\
\text { the processes of adapting } \\
\text { the textbook and planning } \\
\text { self-produced materials. }\end{array}$ & \\
\hline $\begin{array}{l}\text { Category } 3 \\
\text { Influence of } \\
\text { materials on the } \\
\text { teacher's } \\
\text { methodology }\end{array}$ & $\begin{array}{l}\text { To what extent do } \\
\text { materials condition } \\
\text { teaching } \\
\text { methodology? }\end{array}$ & $\begin{array}{l}\text { The influence of materials } \\
\text { on methodology. }\end{array}$ & $\begin{array}{l}\text { To examine the relation } \\
\text { between materials and } \\
\text { methodology. }\end{array}$ & \\
\hline
\end{tabular}

Table 1. Categories, contents and questions associated with the questionnaire and case studies 
The section below describes the schools in which the case studies were carried out and details the procedures followed for analysing the teaching material used by the two teachers.

\subsection{The case studies: Context and analysis of materials}

The description below of the work environment of the two teachers provides a context for their statements of opinions and aids our overall understanding of their situations..

Both teachers were specialists in nursery education at different state schools in the province of Huelva (Spain). The first case, Teacher 1, taught a class of three-year-old and was new to bringing innovation to her teaching, while the second, Teacher 2, taught a class of four-year-old at a school in a coastal town and had substantial experience of innovation.

The research programme was divided into two phases. In the first of these the researcher made the initial approach to the participants and carried out the necessary negotiations and planning, as a result of which it was agreed that the teachers would contribute in the following aspects:

- establish the learning objectives;

- actively participate in the design or adaptation of the teaching materials to be used in class;

- carry out the proposals developed within the framework of the collaboration;

- use the data gathering tools agreed in advance; and

- participate in reviewing the transcriptions and other research data.

Finally, the teachers were guaranteed total confidentiality and anonymity in respect of all contributions as a condition of participation.

The second phase saw the development of the respective teaching modules. For hers, Teacher 1, adapted the unit "The storyteller. Professions", from a textbook for 3-year-old published by the Edelvives company. Teacher 2 made her own material on the topic of "Healthy Eating", with the help of a bank of up-to-date resources. Details of both experiences are available in García-Prieto, López and Correa (2013) and Morcillo and Romero (2013).

At the same time that the case studies were set in train, a review of the two teachers' teaching material was also carried out, as described below. 
This review, targeting the core material used by the teachers, was based on the premise that there is an unquestionable relationship between the quality of teaching material, the teacher's professional development and practice (Pingel, 2010; Cañal, Travé \& Pozuelos, 2011), albeit one which is neither mechanical nor simple. That is to say, good teaching material in the hands of inexperienced teachers may not always result in effective learning, and vice-versa, moribund material can be brought surprisingly back to life by talented teachers to deliver outstanding results. Nevertheless, that the quality of the materials used can impact learning is a factor worth taking into account.

The tool used for evaluating the material employed by the two teachers was the Guide for Evaluating Teaching Materials and Development (ETMD) (Travé, Pozuelos, Cañal \& Rodríguez, 2016), which considers material in terms of six aspects:

- epistemology;

- axiology;

- psychology;

- pedagogical elements:

- key competences,

objectives,

- contents (conception, organisation, and connection with the environment),

- methodology,

- activities (conception, type and sequence),

$\circ$ assessment;

- teaching design; and

- professional development.

The indicators, for evidence of which the data was analysed, lay along a hypothesized progression in Social and Natural Science teachers' thinking and practice, as agreed by expert opinion via the DelphiTechnique (Green, 2014), involving seven lecturers from different Spanish universities and eight practising teachers. The indicators constituted the following levels:

- Indicator A: teaching model proximal to inquiry learning, as arrived at by the expert opinion (rating: 0) 
- Indicator B: teaching model proximal to the transitional model: valuing technology and spontaneity (rating: 1 )

- Indicator C: teaching model proximal to the transmission-conventional model (rating: 2)

- Indicator D: teaching model associated with alternative models, or similar to the above (rating: $0,1,2$ or 3 , according to degree of match with above indicators $\mathrm{A}, \mathrm{B}, \mathrm{C}$ or $\mathrm{D}$ respectively).

A Teaching Material Quality Index was calculated according to the procedure described in Travé, Pozuelos and Cañal (2016), taking the average of the whole-number ratings for the indicators in each dimension. The smaller the difference of the ratings from the expert opinion (rating: 0 ) the higher the quality of the teaching material, while conversely the greater the difference, the lower the quality. The overall Teaching Material Quality Index (TMQI) was calculated using the formula TMQI = $1-/ 3$. The comparative results from the analysis of both teachers' TMQI ratings are discussed in section 3.2 below.

\section{Results}

\subsection{Personal and professional profile of respondents}

This section summarises the general background information supplied by the 864 respondents to the questionnaire directed at nursery and primary teachers throughout Andalucia, and provides the essential context for the subsequent categories in the questionnaire to be interpreted in the corresponding sections below.

The mean age of the sample was 43, and the modal interval that of 31-35 (20.7\%). In terms of sex, three quarters $(74.9 \%)$ were women, and $25.1 \%$ men. With respect to the location of the schools, all eight of the provinces which make up Andalucia were represented, each accounting for at least $10 \%$ of the questionnaires, which fulfilled the intention mentioned above of gathering information from all parts of the region. The distribution with respect to levels taught was over three-quarters $(77.9 \%)$ primary and $22.1 \%$ nursery, with each of the three cycles comprising the primary level accounting for approximately $19 \%$.

Over half $(54.7 \%)$ of the respondents acted as tutors and $17.7 \%$ as coordinators for one of the twoyear cycles into which this educational phase is divided. The mean length of service was 19.9 years, with the highest number of teachers $(25.8 \%)$ pertaining to the $21-30$ years band. The mean length of 
service in teaching the subject Natural and Social Sciences was 17.4 years. The modal value with respect to the number of pupils per class was 25 , accounting for $22.2 \%$ of cases.

\subsection{The Teaching Material Quality Index and the case studies}

In this section we present the analysis of the teaching material used by the two teachers, according to the Teaching Material Quality Index (TMQI) described above.

For dimension 1 - epistemological aspects of teaching material -the first teacher's material received a rating of 2 , in that it identified classroom knowledge with scientific knowledge. From this perspective, it is assumed that a child's everyday knowledge is essentially wrong. By contrast, the second teacher's material received a rating of 0 , as there was evidence of the underlying view that school knowledge comes about as the result of the interaction between scientific and everyday knowledge.

In the second dimension - axiological aspects - both sets of materials received 1 for their inclusion of cultural elements and promotion of respect for the environment.

The third dimension, psychological aspects, takes into account the kind of learning promoted by the material and the role of previous knowledge. With regard to the former, the materials from the first case study received 1 as they were adjudged to bear little relation to the ideas and interests of the pupils, while the materials from the second case study received 0 , the evaluation here recognising that the materials sought to promote meaningful learning by relating the pupils existing ideas with new information from various sources. With regard to the latter, the role of previous learning, both sets of materials received 0 , as they were viewed to start from the pupils' knowledge and interests and to develop these over the course of the teaching and learning process.

Dimension 4 -pedagogical elements - brings into consideration key competences, objectives, contents, methodology, activities and evaluation, each of which will be taken in turn below.

With regard to key competences, Teacher 1's material received 2, as it dealt adequately with very few of these; by contrast, Teacher 2's received 1, as it covered a number of the competences sufficiently well.

In terms of objectives, both sets of materials received 0 , given that both were oriented towards the process of building concepts, models, procedures and key attitudes. 
The contents section was divided into the three subcategories of (a) conception, (b) organization, and (c) connection with the environment. In the first of these - conception - the material from the first case study received 1 , the objectives being evaluated as the assimilation by the pupils of information from the textbook and other media, while that of the second case study received 0 , as here the objectives were evaluated as the intersection of all information from various sources and actors in the construction and development of school knowledge. In the second subcategory -organization - the ratings above were repeated, with the first set of materials receiving 1 , on the grounds that the contents were organized in terms of an exhaustive summation of topics in linear sequence, while the second set received 0 , as it adopted an integrated syllabus arranged in a spiral sequence. Finally, in the third subcategory - connection with the environment - both sets of materials received 0 , in that both oriented their content in terms of direct interaction of the pupils with their immediate social and natural environment, and their personal experiences both inside and outside the school.

With respect to methodology, the material in the first case study received 1, as its methodological approach tended to the non-directive, spontaneous model, while the second case study received 0 , as it adopted an inquiry-based methodology.

The section considering activities was comprised of the three subcategories of (a) conception, (b) type, and (c) sequencing. The first of these again reflected differences between the two sets of materials. While the first received 1 for its offer of practical tasks which complemented a "normal" expository mode, the second received 0 for fulfilling the definition of an organised set of tasks for the pupils and teacher, with an educational objective and requiring different materials and sources of information. With regard to type, the ratings were repeated, with the first case study receiving 1 point for the descriptive and explanatory orientation of its theoretical activities, which were applicable to the textbook or other sources (bibliographic or multimedia), while the second received 0, as its activities were of a theoretical-practical design, involving tasks of description, explanation and argumentation, and requiring a diversity of materials and sources of information. Finally, in terms of the sequencing of activities, the first case study received 2, as it gave a list of activities without any discernible order or structure corresponding to the teaching material, while the second case received 0 , in that it offered a sequence of an appropriate range of activities covering introductory, developmental, structuring and summarising modes.

The final element of dimension 4 - evaluation - returned a 0 rating in both cases, as both conceived of evaluation as a process of understanding and reflection for improving teaching and learning. Pupils, 
teachers and materials were evaluated with various instruments (journals, examination of notebooks, tests and interviews).

Dimension 5 - teaching design - once again underlined the differences between the two case studies. The first set of materials received 1, for the reason that it was based around the textbook with other complementary material, while the second set received 0 for the reason that it was based around selfproduced materials complemented by various other resources.

Finally, examination of dimension 6 -professional development - gave 1 to the first case, in that the material maintained the school routines, such that professional development depended on the commitment of the individual teacher. The second case received a 0 rating, as the material promoted the design, development and evaluation of the syllabus from an enquiry-based perspective.

The total number of points for each set of materials deriving from the analysis of the six dimensions above resulted in the following overall ratings on the Teaching Material Quality Index. The first case achieved a rating of 1.05 , indicating that the material in question had limited educational merits, being focused on a textbook which the teacher took it upon herself to complement so as to cover perceived omissions and errors. By contrast, the second case achieved a rating of 0.19 , very close to the expert opinion of 0 . In this instance, the material has considerable educational merits, as a teaching project based on inquiry learning.

\subsection{Analysis of the research categories}

In the following section we present the analysis of the three research categories.

\subsubsection{Teaching materials: textbook versus self-produced material}

With respect to teaching material, it was found that the majority of respondents $(95.1 \%)$ used a textbook, as opposed to $4.9 \%$ who stated that they did not. The publishers, in order of frequency, were Anaya (29\%), Santillana (20.7\%), SM (10.7\%), Edelvives (5.1\%), Everest (3.4\%) and Vicens Vives (3\%), along with others of relatively low frequency. 


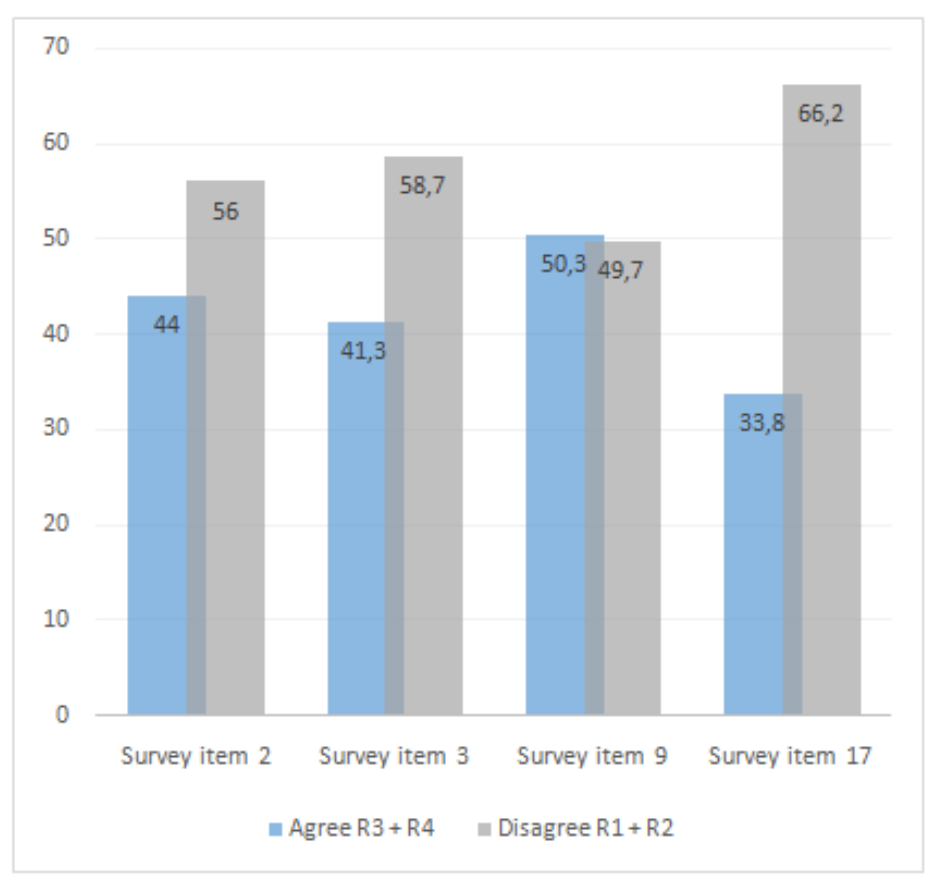

Figure 1. Teachers' opinions of textbook use

When the evaluation of the textbook used in class is considered, as summarised in Figure 1, it is noteworthy that, despite their predominant use, the teachers' opinions are largely critical of their potential benefit to the pupils. Some $56 \%$ of respondents disagree that the activities in the textbook promote the study of specific aspects of the child's social and natural environment (question 2), a point of no small importance given that this is the very area that is supposed to be the focus of study. More surprising still is the result of question 17 on the capacity of the textbook to facilitate the active participation of pupils in learning about, understanding and developing their appreciation of their environment, to which $66.2 \%$ of teachers responded in the negative. Nor was there a positive response to the textbook's potential for achieving comprehension and significant learning of the topic, with six out of ten teachers giving a negative answer (question 3). In the light of these findings it is inevitable to question the wisdom of continuing to promote the widespread use of textbooks in class, as the authorities in Andalusia continue to do through their annual free textbooks campaign, when the majority of teachers question its validity as a resource for tackling essential features of the syllabus. In order to understand the reasons why so many teachers decide in favour of using a textbook, besides the policy of providing free class sets, supported by $50 \%$ of the teachers (question 9), we explored their perceptions regarding its utility (question 46). The findings here indicate that the majority of respondents consider that using a textbook saves time (73\%), lightens the workload by offering a 
sequence of activities (79\%), allows teachers to choose contents $(62.5 \%)$, enables parents to follow the course (76.4\%), and provides security and confidence (77.1\%).

In the textbox made available for "clarifications and doubts", comments on the advantages of using published textbooks refer to "convenience" (questionnaire numbers 68, 564 and 711), "labour savings" (questionnaire 134), its role as a guide to the contents (questionnaires 167, 296 and 620), and its value in reducing uncertainty and avoiding "improvisation" (questionnaire 336). These evaluations demonstrate that the textbook represents a valued source in that it simplifies the job of designing and developing classroom materials.

With regard to self-made materials, approximately a fifth $(22.2 \%)$ of the respondents stated that they created teaching units and other complementary material, while only $5.4 \%$ said that they used the teaching units published by the Regional Education Authority, in consonance with the tendency of recent decades, which have seen a decline in the use of material made by the teachers themselves (Pérez Gómez \& Gimeno, 1994).

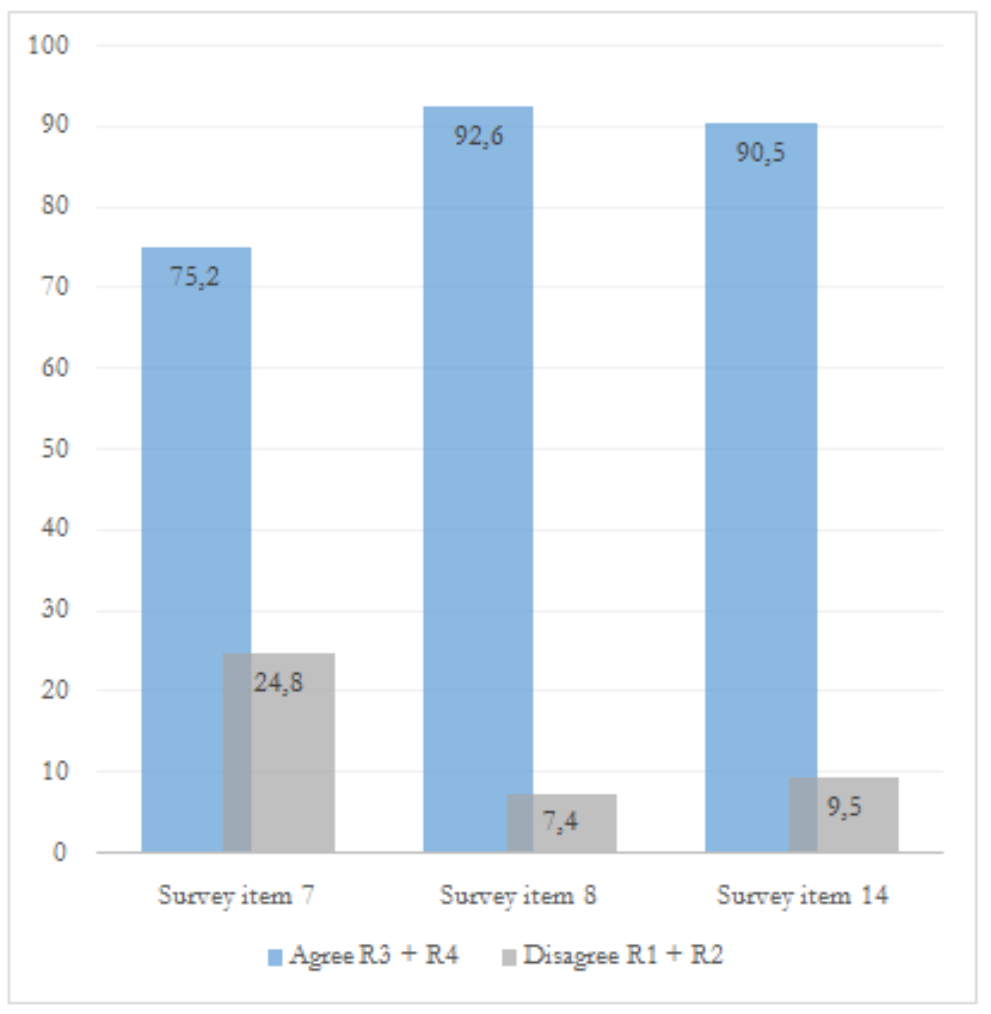

Figure 2. Teachers' opinions of self-produced materials 
The data from the questions about the use of self-made material (Figure 2) give a very different picture to that concerning use of the textbook. Here, $75.2 \%$ of respondents affirm that the study of the environment in teacher-produced units of work focuses on the place where the school is located (question 7). Further, over $90 \%$ of teachers agree that teaching units based on giving the pupils opportunities to do research promote meaningful learning (question 8). A similar result was obtained regarding the statement that teachers should have at their disposal material which has been tried and tested in the classroom, with which $90.5 \%$ were in agreement.

The questionnaire also explored the perceived advantages of making one's own materials (question 50). Although, as reported above, only a minority of teachers did so, respondents identified the following advantages of taking this approach (the corresponding percentages are also indicated): it facilitates project work (question 50 (a) - 87.9\%); it contextualizes teaching (question 50(b) - 88.3\%); it allows teachers to focus on the pupils' ideas and interests (question $50(\mathrm{c})-89.1 \%$ ), and it is motivating (question 50 (d) $-85.8 \%$ ).

Respondents complemented their answers to question 50 with some qualitative observations. In broad terms, these indicate that although self-produced materials are recognised as a valuable alternative in terms of promoting contextualised and meaningful learning, there are also limitations such as the lack of time (questionnaire $n^{\circ} 375$ ), the need to form work groups in order to produce them (questionnaire $\mathrm{n}^{\circ} 449$ ) and increased uncertainty regarding fulfilling syllabus requirements (questionnaire $\mathrm{n}^{\circ} 779$ ).

The data reflect two broad attitudes towards the use of teaching materials, but However, give little information about how these two approaches translate into actual classroom practice. Light on this aspect, nevertheless, was shed by the results of the case studies, providing the complementary view from the classroom.

The teachers taking part in these designed and developed different types of materials to use in their classroom teaching. Teacher 1 used a textbook from an established publisher (Edelvives), whereas Teacher 2 produced her own materials from a variety of resources. Both teachers went about their work with confidence and self-esteem, essential aspects of their professional identity (Zembylas, 2004).

As stated above, the first teacher habitually used the textbook, as is the case with the majority of teachers in Spain. According to the teacher, the choices involved in deciding on the material are taken by all members of the teaching staff. "In the nursery division in this school, we use materials from the Edelvives publishing house, because the teaching staff consider them better suited to the context and the children we have here" (63:16, 2804:2804. Interview with Teacher 1). 
The teaching material employed on this occasion was unit eight in the textbook for three-year-old entitled "The Storyteller". It focused on the topic of jobs, and the teacher aimed for " the children to learn the names of different jobs and learn more about them, making their knowledge more immediate through role-playing games and visits" (63:1, 2500:2500. Notebook, Teacher 1, pp. 74).

The teacher used various materials and resources. The classroom shelves were full of objects and toys, among other items. The classroom walls were decorated with the pupils' work, displaying 'toque blanche' chef's hats and gloves made of paper, as well as murals with worksheets and drawings. The teacher, however, had added new resources to those in the book: "The book offers a story entitled The Storyteller', but it was uninspiring and had no relation to the jobs closest to children. I decided to include the tale of 'The Pastry Chef Dragon', which I've adapted for the purpose" (63:2, 2523:2523. Notebook, Teacher 1).

Scheduled activities were based on the collection of exercises included in the textbook. The teacher also designed other tasks to arouse the pupils' interest in discovering their immediate environment. Among the motivating activities chosen to this end were excursions and field trips to find out about the jobs of firefighters and gardeners, cooking workshops, sessions at the school allotment to learn about handling utensils, and role playing games involving various jobs. "I hope that when we're finished they will be able to answer questions like, Name some jobs. What do they do? What tools and vehicles do they use? What kind of clothing do they wear and why? What do you want to be when you grow up?"'(63:3, 2501:2506. Notebook, Teacher 1).

On the other hand, Teacher 2, rather than follow textbook, was more openly inclined towards materials from a variety of sources including her own. Among other reasons, she explained that "It would be very difficult to work on an enquiry-based project on the basis of a single resource". 65:30, 432:432. Interview with Teacher 2). She held the opinion that published material represented a closed resource with very little connection with pupils and their particular context, and offered uninspiring activities and content of limited educational value. Ultimately, textbooks " are very limiting, because materials from the publishers don't match their [the pupils'] interests. They have simple exercises with no complexity at all" (65:33, 653:653. Interview with Teacher 2).

The subject matter chosen for the project was Healthy Eating, and was taught from a functional perspective, linking directly with the promotion of health and the acquisition of good habits. The study of diet "... is attractively presented, through multiple activities and practices which should also be suggestive and motivating (field trips in the surrounding area, experiences, observations, practices, creations, etc.)" (65:1, 539:539. Notebook, Teacher 2). 
The teacher sought out resources and prepares materials in very different formats: printouts, tangibles, digital material and contextual items. As the teacher explained, "they need to work with very different materials; there are many different kinds of media and we can't reduce it to only one". (65:26, 378:378. Researcher's journal).

Occasionally this task becomes excessive: "I find myself somewhat snowed under with the round robin books (reading, revising, distributing, etc.) and there are so many things at once that demand my attention: resources that they bring with them from home, responses to what they've worked on with their parents, etc. And all this within the time we have". (65:2, 369:369. Journal, Teacher 2). There is no getting away from the intensification of work involved for the teacher in preparing resources. To reduce this, she resorted to involving parents, which aided her work: "Family participation and involvement throughout the process is a resource of inestimable value, and in this case, the results are very favourable". (65:3, 563:563. Notebook, Teacher 2).

In addition to teaching resources, materials were also produced to help understand and analyse the teaching which was being carried out. To this end, video recordings, photos and journals fulfilled the objective of gathering evidence to improve teaching actions and outcomes: "Photos were taken and videos recorded of the outing" (65:5, 318:318. Journal, Teacher 2), "We recorded the lesson..." (65:6, 393:393. Journal, Teacher 2) and "I'm putting together a photo album to record the experience of this project throughout the entire process with all its specific activities". (65:7, 383:383. Journal, Teacher 2).

Teacher 2's practice was characterised by the inclusion of diverse and complementary materials, consistent with a specific pedagogical approach (enquiry learning) and incorporating the substantive involvement of teaching colleagues and other collaborators. As can be appreciated, it is not simply about consuming resources; the creative action for adaptation and development also counts. And this also holds educational potential that fosters the professional and social development of all participants.

In summary, we have seen from the data gathered from the questionnaire that the majority of teachers make use of the textbook despite recognising its disadvantages. This admission can be appreciated in the first case study, in which the teacher employed a textbook while being aware that it was not the ideal resource, and as a result felt obliged to compensate its shortcomings with activities and materials from various sources. In contrast, a much smaller proportion of the sample from the questionnaire used their own teaching materials, consistent with the majority opinion that these offer significant advantages to the teaching/learning process, as evidenced in the second case study. 


\subsubsection{The role of teaching materials in lesson planning}

In the first part of this section we present the results from the questionnaire about the role of materials in the process of planning a series of lessons, specifically in connection with the following syllabus elements: key competences, methodology, activities and evaluation. The process of creating teaching materials is also considered.

We begin with an examination of the data concerning teachers' opinions on key competences (Figure 3). The majority, specifically six out of ten, consider that the practical activities in textbooks for the Social and Natural Sciences are insufficient to develop the competence of interacting with the environment (Question 25a). The respondents viewed textbooks as similarly insufficient in the other competences: $61.7 \%$ for society and citizenship (Question 25b); 65.6\% for culture and art (Question 25c); and 69.3\% for learning to learn (Question 25d).

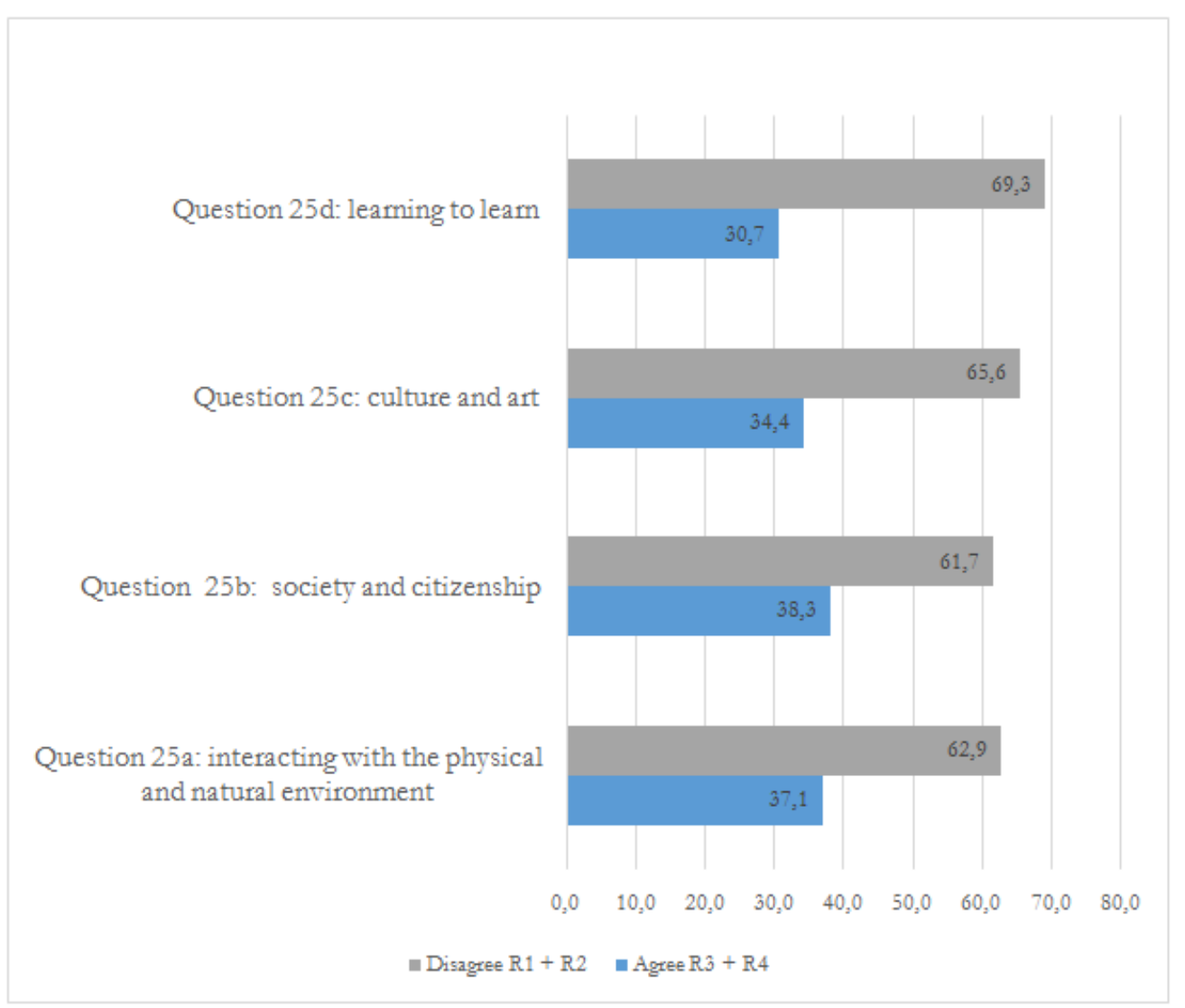

Figure 3. Teachers' opinions of the treatment of competences in textbooks for the Social and Natural Sciences 
The results of the remaining questions in this category are presented in Figure 4 below. For contents there was an evenly balanced response, with $50.7 \%$ agreeing that textbooks dealt adequately with the key concepts in the social and natural sciences (time, space, living organisms, ecosystems, machines) (Question 45).

In terms of methodology, the majority opinion $(62 \%)$ agreed that textbooks tend to promote a conventional, transmission-based methodology (Question 5).

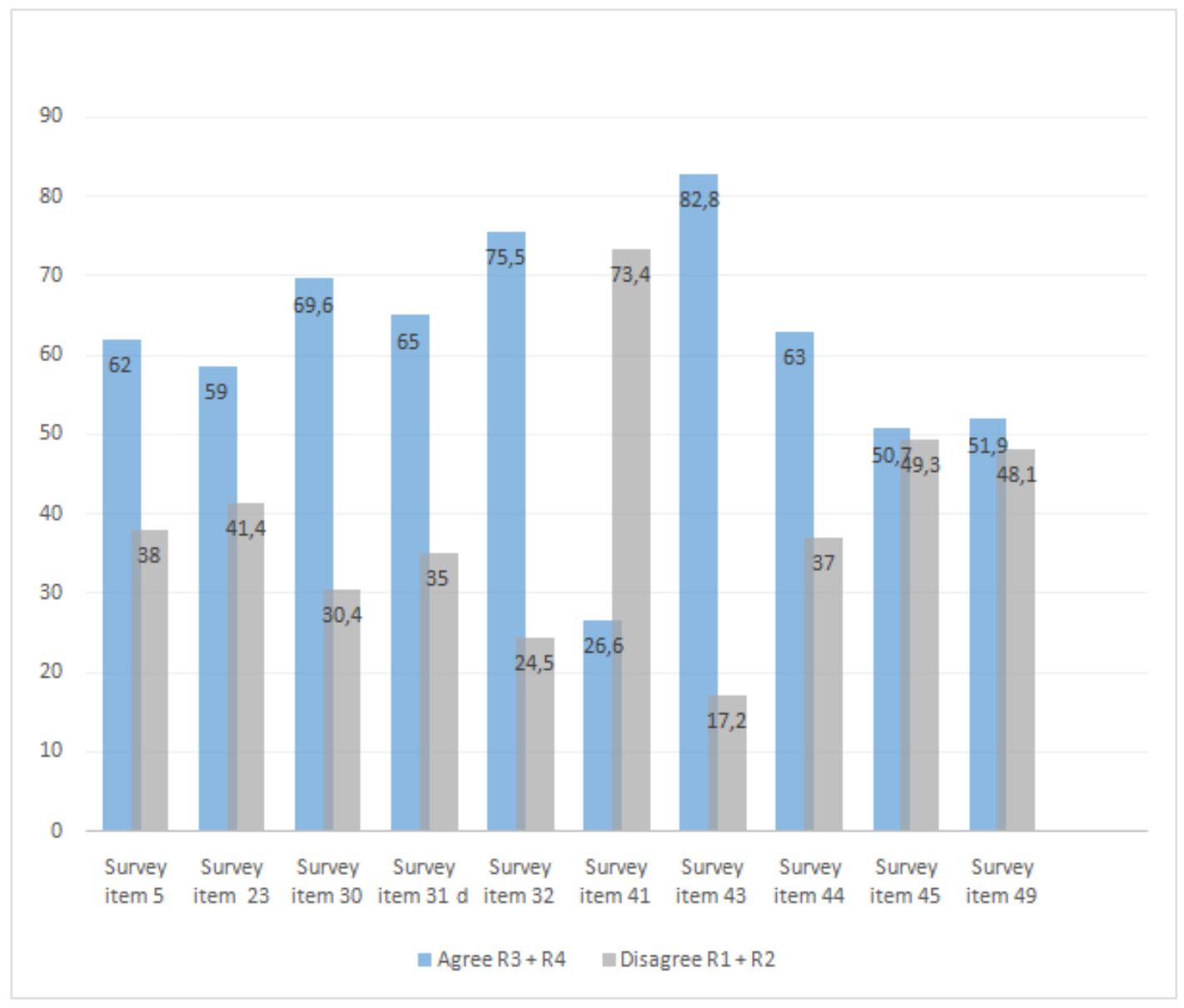

Figure 4. Teachers' opinions of the role of teaching materials in lesson planning

Regarding the other dimensions, $51.9 \%$ of respondents state that they used teaching materials oriented towards finding solutions to problems of relevance to the pupils and their immediate community (Question 49). A higher percentage (69.6\%) stated that using teaching units and other teaching 
materials enabled them to adequately study questions about their environment with their pupils (Question 30).

The general panorama in terms of the kind of classroom activities teachers carried out in the social and natural sciences presents a picture where $73.3 \%$ did not organise any out-of-school trips (Question 31b), some $53.4 \%$ did not programme either activities involving experiences or practical sessions (Question 31c), 54.8\% did not use group work (Question 31e), and 55.6\% did not use ICT in their lessons (Question 31a). This latter situation was clearly influenced by the fact that six out of ten respondents noted the lack of ICT resources as part of the textbook package (Question 18). The most frequently used activity in lessons was class debates, an activity employed by $65 \%$ of the teachers (Question 31d).

One of the implications of using a textbook in class which was appreciated by respondents was the need not to have to continually explain to the pupils how to do the activities (63\%, Question 44). Another factor which received a high degree of approval $(82.8 \%)$ was the availability of a wide range of materials which could be adapted to teachers' circumstances (Question 43).

With regards to evaluation, $58.6 \%$ of teachers said that they carried out a spoken or written test of the contents of the textbook (Question 23). However, 73.4\% stated that they did not use the tests provided by the teacher's book for determining pupils' final grades (Question 41), but instead, 75.5\% assessed their pupils summatively in terms of class participation and individual and group work done in class (Question 32).

The need to respond to the perceived limitations of using the textbook as the only resource are illustrated in the following section describing the work of the teachers in the two case studies.

In terms of progression along the cline running from complete to 0 dependence on the textbook, Teacher 1 was at a transitional stage towards independence. She was not hermetic in her use of the textbook, but the topics she chose for her programme of study were the same. To a great extent, she also chose the objectives proposed by the textbook: (63:5, 233:233. Teaching programme, Teacher 1): "To find out about some of the occupations of men and women in our surrounding area, to identify certain jobs and services connected with health and safety, and to be able to recognise the most characteristic instruments and uniforms of each job". These objectives were expressed in very similar wording to the textbook, although she added new items including the occupations of farmer and gardener, and emphasised gender equality in various (formerly unequal) jobs including firefighter, baker, cook, confectioner, doctor, police officer and waiter (63:6, 255:255. Teaching programme, Teacher 1). 
The sequence of activities in the textbook was structured around a set of exercises aimed at developing the pupils' fine motor skills. The exercises represented a fragmented way of working, somewhat unconnected to the topic in hand, which the teacher attempted to adapt to her class with uneven results. "The exercises in the student book were very simple, with rather poor decontextualised content. The solution was to use this material, but expanding the contents included in the book". (63:7, 2525:2525. Notebook, Teacher 1). She also used various everyday materials for introductory activities to explore the pupils' existing ideas of the topic. In this case, she used a "magic box", like a conjurer making objects, toys and people appear and disappear:

Teacher: Here comes a firefighter...! What does a firefighter do?

[The pupils simulate riding on a fire truck, making the sound of the siren.]

Teacher: And what else does a firefighter do? Where are we going with the fire engine?

Pupil 1: To rescue a cat.

63:8, 1303:1308. Video recording transcript

Revision activities included 'The Book of Jobs', a small booklet prepared by each child over the course of the unit, which the teacher used to go over previously learned items:

Teacher: ...we find several jobs and the tools that go with them.

[The pupils look at the drawings of the farmer.]

Teacher: What tools do they use? What do they harvest?

63:9, 2754:2754. Researcher's journal

Another activity consisted in dramatising the profession each child finds appealing.

Teacher: 'T'd like to be...

[All the children describe what they want to be.]

\section{3:10, 2754:2754. Researcher's journal}

The system of assessment carried out by Teacher 1 was highly formative and qualitative. It took account of the children's previous ideas about the subject and followed the format of "games and 
dialogues in the assembly, where everyone expressed their opinions and what they had learned" (63:11, 2517:2517. Notebook, Teacher 1).

Teacher 2 planned her teaching around specific topics aimed at developing her pupils' all-round skills. Her approach to the topic of 'Healthy Eating' was functional, "so that it isn't just about what they know" (65:42, 421:421. Interview, Teacher 2).

She planned her teaching without relying on published material, but instead consulted a range of authoritative textual sources and then "made a first draft after consulting various documents - books, magazines, websites, the literature from official regional government campaigns, etcetera" (65:4, 541:541. Notebook, Teacher 2). She then presented this outline to her pupils, encouraging them to contribute ideas and questions to give the final shape to the programme for the project. This "teaching consultation" involved the use of various resources made by the teacher herself, including a computer presentation to elicit the pupils' responses to the outline and a system for making sure that everybody had the opportunity to contribute to the proceedings. The key elements in this approach, the thematic outline, fact-checking, consultation and resultant adjustments together constituted a soundly informed participative process.

When explaining the reasons for her choice of topic, the teacher emphasised that it is " a socially relevant area, and one that connects with the core curriculum contents; not forgetting that it allows a range of different practical activities that can be used in class". (65:44, 328:328. Researcher's journal).

The objectives defined by the teacher "... are open-ended and, in this sense, represent signposts to guide the development of the children's experiences, rather than closed goals for all the pupils" (65:8, 49:49. Teaching programme, Teacher 2).

The organisation of the content integrated different areas and knowledge "... as a related whole that admits different, mutually consistent contents and knowledge" (65:9, 84:84. Teaching programme, Teacher 2).

The chosen objectives and contents involved various aspects of life, the development of personal and social values and everyday procedures associated with diet: "We've been following an integrated scheme that ensures the connection between different knowledge sets and experiences, which helps pupils to understand what they are learning and its relevance to everyday life". (65:10, 553:553. Notebook, Teacher 2). These experiences included aspects as diverse as hygiene, commensalism, responsibility, task sharing, artistic sensitivity, the market, purchasing, budgets and more, which are rarely to be seen in typical lessons even in the most wide-ranging textbooks.

The planned activities included various modes of working on the topic, such as: 
- Practical experiences: "As I see it, the pupils in the cookery workshop seem quite active and very interested". (65:11, 382:603 382. Journal, Teacher 2).

- Interaction with the local surroundings: “...activities that bring the pupils into contact with real-life; we have made several trips around the town: the fruit shop, supermarket, bakery et cetera., so that the educational experience opens up to the surroundings and allows a flow between the school and the outside world". (65:12, 552:552. Notebook, Teacher 2).

- Using technology: “... another group has been working with the computer and the Internet. They are just starting to learn to use these resources for activities in the project: they love the computer and you can see they are quite capable”. (65:13, 398:398. Journal, Teacher 2).

- Games as an educational resource: "... different games which were organised in the classroom and which promoted different kinds of learning" (65:14, 556:556. Notebook, Teacher 2).

In short, the programme offered of a variety of activities governed by explicit criteria - "Contact with the real world. A collaborative approach. Teeaching for diversity. Participation of the family and other stakeholders. Active participation". (65:15, 550:550. Notebook, Teacher 2) - all aiming to transcend purely academic knowledge based on "correct answers", of little use beyond the context in which it was acquired.

As can be seen, the teacher aimed at all times to ensure that the pupils shouldn't measure out their classroom lives with interminable exercises: “We did murals, dramatisations, field trips, conversations, direct experiences and lots of preparatory activities; it's not reduced to simply filling in an exercise on paper". (65:48, 579:579. Interview, Teacher 2).

This variety of experiences and activities was possible thanks to the participation of different collaborators (families and other volunteers), as "without this participation it would be very difficult to carry out the projects; one person alone would find it very hard". (65:50, 587:587. Interview, Teacher 2).

The pupils were assessed by means of a formative procedure which aimed to promote sound, lasting learning, and consisted of a series of varied activities, including mini-dramas, an album of the project, a question and answer game, computer presentations and on-going lesson reviews. The range of activities enabled different expressions of learning to be assessed, and not merely the 'right answers' to one-dimensional closed questions. "For the purposes of assessment, among other resources, we use drama, an album where we stick everything important, along with photos, because you can't put a lot of experiences down in writing, whereas photos give you a perfect idea of how an activity went". (65:53, 564:564. Interview, Teacher 2). 
The teacher was not dependent on any single media or project. There were many decisions to be taken (with respect to content, resources, activities, organisation, assessment, and so on) in order to fine-tune the teaching sequence to the particular pupils and their context, which could not be done with a single textbook. As she states, the activities brought into play "are not dull experiences for the children, they are not monotonous. The chldren are enthusiastic about them" (Interview, Teacher 2).

The above exposition of the data gathered from the second category - the role of materials in lesson planning - has shed light on the influence exerted by different materials on the teaching process. The findings of both the questionnaire and the case studies illustrate how teachers take very different approaches to using a textbook or their own material. The choice of one type of material over the other has implications for other aspects of the syllabus. Hence, while those using a textbook are largely bound by external constraints on their design - irrespective of whether they are able to complement this with additional resources - those using their own materials are free to exercise control over the design and execution of their teaching.

\subsubsection{The influence of teaching materials on methodology}

The final category in the study examines the relationship between materials and methodology. In this respect, comparison of the two types of materials highlights substantive differences between using a textbook as opposed to self-produced material.

Hence, while $75.7 \%$ of teachers disagree that use of the textbook has a positive impact on their development as teachers (Question 28, Figure 5), 85.7\% do recognise that the creation of their own teaching materials as a significant factor in pushing their professional development forward (Question 39).

In the same vein, not only was the process of designing and creating materials highly regarded, but $74.1 \%$ of respondents also agreed that their use in class was valuable.

Consistent with the overall picture derived from the questionnaire data, the implications of choosing one type of material in favour of another become equally clear when the classroom practice of the two case studies is examined. In the first case, where the textbook predominates, the teacher and pupils' tasks were determined by this material, which directed what happened in the class. It is evident that the main teaching decisions taken by the teacher (objectives, contents, activities and so on) pertained to the textbook, even though she provided additional material and experiential activities in view of the rather 
inadequate treatment the book gave to the topic of jobs: "I personalize the organisation of the textbook and adapt it to my own way of understanding the process of teaching and learning" (Questionnaire F, Question 82).

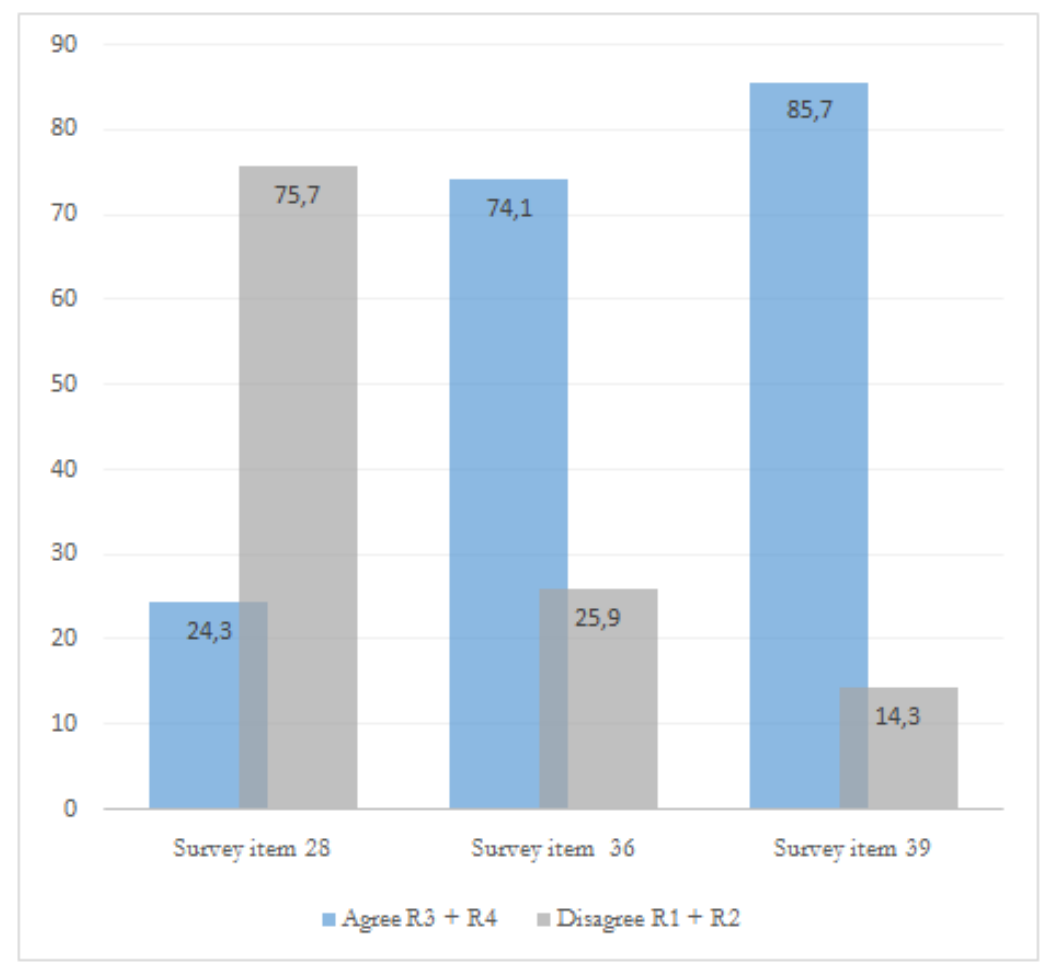

Figure 5. Teachers' opinions of the impact of materials on methodology

The teacher based her approach on the principle of maintaining activity, as she considered that children "learn by doing". To this end, she focused on their communicative and musical skills to obtain their full involvement. She expertly managed the materials and resources, and achieved positive results in getting her three-year-old pupils to concentrate and participate. For example, she took a 'magic bag' from the shelf and uses it to elicit the names of different jobs.

Teacher. Let's see what comes out of the magic bag...

Pupils. A cap!

T. Who uses it? What is it for? ..."

63:12, 1807:1816. Video recording transcript 
Activities such as tending the school allotment and trips out were combined with drama activities in which the pupils play-acted everyday situations with a view to stimulating curiosity, empathy, body language and self-esteem in the pupils.

[The teacher introduces the topic of jobs.]

Teacher: Do you know who slides down a pole?

Child: Firefighters.

[The children play act the job.]

63:13, 2612:2612. Researcher's journal

The teacher explained the design and implementation of the unit, affirming that the book was just another resource among those she used. Her flexible use of the textbook has undoubtedly favoured the achievement of the stated objectives. "When it came to covering this unit, I had to use a lot of my own resources (support materials, activities, games and so on). The textbook, both the teacher's and the pupil's book, were useful to me as another resource to take into account, not as something fixed that you have to follow. I'm the one who decides what I use, trying to ensure that they determine what I do as little as possible" (63:14, 2521:2521. Notebook, Teacher 1).

At this point, Teacher 1 was going through a period of transition between a conventional methodological approach and something more active and innovative in nature (Cañal et al., 2011), as she expressed enthusiastically: "Despite the burdles, I'm very satisfied with the work carried out. I think the pupils have had a really good time; they've learnt what I intended, as well as some other things which cropped up along the way." (63:15, 2530:2530. Teacher's Journal, Teacher 1).

When we observe the class dynamics of Teacher 2, we can note the relationship between the materials and the kind of teaching which takes place. It would not be possible to carry out an enquiry-based lesson using a single closed resource such as a textbook or its equivalent (worksheets, etc.). Nor do these materials fit well with open-ended and creative activities. By contrast, the materials she used were compatible with the twin educational principles of autonomy and cooperation which guided her approach, insofar as they "encourage shared learning and peer interactions (murals, corner shop, workshops, etc....) while facilitating socialisation and multiple relations among equals". (65:56, 125:125. Teaching programme, Teacher 2). 
Participation was extended to the home and community spheres. The involvement of the family and other stakeholders became commonplace and customary. Everyone was involved in providing resources, not only for their material value but also for the collective feeling with which it imbued the educational activity, "Because in order to learn properly, we all need to participate. Only then do the contents take on their true meaning". (65: 54, 527:527. Interview, Teacher 2).

The materials aimed not only to guide the students in gathering and collating information, but to enable them to produce knowledge, too:. "In addition to looking for information, we want them to be able to make, create, and present results and answers to the questions". (65:60, 493:493. Interview, Teacher 2).

In brief, they heard about a variety of experiences (talks from people with an expertise), they got to know different loci (trips to a local shop and market), they carried out mini-experiments to learn how to test things and draw conclusions (experimental sessions and kitchen workshop), they accessed information (reference works) and used different technological devices (computers, digital cameras and computer presentations, etc).

Making one's own material has two significant differences with the textbook. On one hand, it means working with resources specifically tailored to the activity and pupils; and on the other, it demands the teacher to reflect on the content and execution of the resultant material. As Teacher 2 noted, "textbooks aren't up to the job for our projects". (65:66, 474:474. Interview, Teacher 2).

After several years of involvement in innovative and investigative projects, the teacher demonstrated that her methodological approach was grounded and coherent. She was able to prepare, find, adapt and create materials which carried through her initiatives without being dependent on other sources or losing educational relevance.

Close study of the two cases enables us to see that the conceptions and practice of the two teachers regarding classroom materials show similarities and differences. In terms of similarities, we can note that both prize innovation as a mark of good teaching, and both favour the use of the immediate environment, a variety of materials, experiential activities, workshops, games and family-school collaboration. The differences mainly arise at the level of methodological development and class management attained by the two teachers. Thus, the Teacher 1 case displayed a lesser degree of autonomy and considerable dependence on the educational decisions enshrined in the textbook, which, for the most part, she was happy to carry over into her teaching. By contrast, Teacher 2 achieved a greater degree of independence by creating materials specific to her context. This created a virtuous 
circle whereby her increased autonomy prompted further professional development in her enquirybased approach, and vice versa.

To finish, our examination of the final research question enables us to say that the choice of one type of teaching material over other influences the way in which the teacher carries out the lesson, and that the processes involved in making one own's material have a positive impact on the teacher's professional development and their mode of teaching. These findings underline the necessity for finding appropriate means of promoting material production among practitioners, taking them from mediators of external packages to experts in the design and implementation of locally relevant resources.

\section{Conclusions and discussion}

The two studies reported on in this paper - extensive and intensive - allow us to explore conceptions and practice regarding the design and exploitation of teaching materials, both quantitatively, by means of a questionnaire, and qualitatively, through the execution of two case studies. The results obtained enable us to formulate the following conclusions, which we will present in the order of the original research questions.

The answer to the first of these - What materials are used in class? - confirms the widely-held belief that the textbook still predominates within the education system, as previous studies have also found (Issitt, 2004; Varela, 2008; Bayona, 2009). Nevertheless, it can be observed that teachers use it in a wide variety of ways and with a wide variety of outcomes (Sosniak \& Stodolsky, 1993), and consequently further classroom-based studies are needed to deepen our understanding of how it can be put to best use (Moulton, 1997). Even in the context of teachers committed to enquiry-based learning, as witnessed in the first case study, the textbook could be seen to constrain the choice of topics. At the same time, however, the use of teacher-produced material was also observed, which allows us to conclude that there is a sector, albeit a minority, prepared to invest in making and implementing their own materials. A clear instance of this can be found in the second case study, in which the teacher was commited to creating her own classroom resoures and eschewed commercially available material. A measure of the quality of the material thus produced is the 0.86 points difference on the Teaching Material Quality Index (TMQI) between this and the material used by the teacher in the first case study. In essence, the comparison of the two cases foregrounds how the adoption of alternative materials is the beginning of a progressive and complex journey, through experience towards ever more fully-developed positions 
regarding teaching (Maestro, 2002; Pinto, 2007; Grossman \& Thompson, 2008; Reininger, 2010). In consonance with previous studies, we note that the simplest way to begin this journey is with the first steps towards a firmer, more well-founded position.

In order to consider the second research question from category 1 - How are teaching materials chosen? - it is necessary to draw attention to the multiple factors, both internal and external, which influence the decision-making process. For example, the implementation of a free textbooks policy across the region of Andalusia means that textbooks are available in schools by definition, although whether teachers make use of them is another question. A definitive answer to the question would require constructing a matrix of teachers' conceptions and practices, the contexts in which they teach, their level of professional development, and their professional trajectory. Nevertheless, although the data show that both textbooks and self-produced materials are highly rated among teachers, it is the former that are used most frequently in class.

Of the various factors which cause the textbook to be used so widely used, we can perhaps highlight two which are key to its being chosen again and again - the issue of time and the reduction of uncertainty. The issue of time is a commonplace among teachers (Adelman, Panton, Eagle \& Hargreaves, 2003; Hargreaves, 1996), and is frequently identified as the main factor in determining what is possible in the educational context. In this respect, it is not beyond the realms of possibility to suggest that the perception of the textbook as time-saving resource has a significant influence on its use, although it would be interesting to investigate to what extent saving time determines the choice of material. Likewise, the reduction of uncertainty is another key factor, to which the textbook contributes significantly by bringing security and confidence through providing a ready-made choice of contents and sequence of activities, as well as allowing parents and guardians to follow their child's progress. Given that a sequential deployment is built into their design, textbooks represent a centralisation of decision-making about the syllabus (Soto, 2006; Campagno, Castillo \& Ferrero, 2009). And if this fidelity to the textbook is broken, it is all too easy for tensions to arise and for there to be conflict between the different stakeholders (pupils and parents as well as the teaching staff), who have become accustomed to the automatic transmission it offers. Conflicts of this nature can delay or even terminate initiatives aimed at complementing the textbook with other resources, or replacing it in some way.

Nevertheless, when we look at the various advantages of the textbook, as identified by respondents, it becomes evident that these are largely limited to how it makes the teacher's job easier. When its potential benefits for teaching and developing the key competences are considered, the panorama is less encouraging still, with the book regarded as decontextualised from the environments in which it is 
used, and likely to inhibit the active engagement of pupils with their environment and the acquisition of meaningful learning. Findings such as these call for the need to undertake further studies to explore the reasons for the widespread use of a resource which at the same time is identified as having serious shortcomings for promoting learning, the ultimate aim of any educational enterprise. Conversely, it would be equally interesting to investigate why self-produced materials, despite being held in high regard by teachers, who underline their innate capacity to exploit the child's immediate surroundings, and their potential for promoting enquiry and meaningful learning, continue to be used by a minority. Hence, our conclusions from the respondents' evaluations of the comparative merits of the different materials are that while the textbook is perceived as facilitative of the teaching processes - in other words, its advantages are judged from the perspective of the teacher - self-produced materials are perceived as an adjuvant in the learning process, with a clear consensus on their benefits for achieving meaningful learning on the part of the students. We are faced, then, with a paradox in which, broadly speaking, teachers employ a textbook despite recognising the greater suitability of the material they could produce themselves.

The narrow focus of the case studies sheds light on why certain materials are chosen in favour of others. The teacher's methodology has a significant influence on the design and execution of their materials. Hence, Teacher 1 finds herself in a period of transition from a more traditional methodology to a more innovative style which places emphasis on the child's experience and follows the principle of 'learning by doing'. The reworking of the textbook represents the teacher's first trial of a new methodology. Teacher 2, in contrast, has a wide experience of project work as a result of her professional development in this area. Her independence and cooperation are fundamental to her approach, and underpin her self-reliance in creating her own teaching materials, adjusted to her particular classroom environment and to the conceptions and interests of her particular pupils. Thus we can conclude that teachers' choice of teaching materials depends in large part on their methodological approach, which in turn is determined by the level of their professional development. Teachers reconsider their conceptions and practice to the extent that, over time, they use or create material which challenges them, a finding which has prompted some commentators to propose a trajectory of desirable progression for using certain kinds of materials (Grossman \& Thompson, 2008; Kasim, 2008, Cañal et al, 2011).

There are published projects available which aim to facilitate the process of creating one's own material and interpreting the syllabus. One such publication is the Project INM (6-12) (Cañal, Pozuelos \& Travé, 2005), which aims to bridge the gap noted by all those who attempt to make the move from textbook 
to their own educational proposals. It offers materials, resources, guidance and examples that can be individually distributed. The project is not widely known and still less studied (Reininger, 2010), although its potential is recognised by all those who have used it. And as many of those have shown, the more independence from textbooks, the more professionalilty and educational credibility one gains (Stenhouse, 1987; López Hernández, 2007).

In response to the first of the research questions in the second category - What role do materials play in relation to the curriculum? - we can note that a majority of respondents saw scant potential in textbooks for developing key competences, whilst they were evenly split regarding their treatment of items on the syllabus, and a majority again judged them responsible for promoting a transmissive methodology and the need to constantly explain how the pupils should do the activities. By contrast, similar numbers noted the virtues of self-produced materials for exploring question of the immediate environment. Also noteworthy is the observation that the majority of teachers carried out written and spoken tests of the content covered in the textbook. This supports the view that the choice to use a particular type of material carries forward with it a clear influence over the type of assessment activities that will be used, even if complementary modes of assessment are used, such as coursework.

At another level, the experience of those who advocate a flexible use of the textbook suggests that those who regard it as nothing more than a simple resource book have a limited view, as the rigorous analysis of the data gathered from the case studies shows. In this respect, it is clearly evident that the most important teaching decisions are taken according to the indications of the textbook, and the participation of the teacher in these is relegated to that of merely deciding on complementary resources or activities from amongst those already suggested by the book. This scenario is completely inverted in the second case study, in which the teacher exercises complete control of all teaching decisions, and carries out her work through a series of inquiry-based tasks and the implementation of her own materials.

Regarding the second research question in this category - "How are teaching materials produced?" - our finding is that there were two approaches depending the teacher's dependence on, or independence from, the textbook. In the case of the former, this involved some reworking of the book, which in some cases, such as that described in the first case study, achieved a degree of creativity and flexibility. This practice of tweaking of the textbook gives the lie to the frequently made observation, as widespread as it is misleading, that "the use of the coursebook invariably leads to uninspiring teaching and rote learning." The latter approach favours enquiry-oriented project work based on sound theoretical foundations. By incorporating a range of materials focused on the pupils' own immediate 
environment and interests, as observed in case study 2, the teacher achieved an integrated approach for functional learning. The approach challenges another widely held generalisation (and equally unfounded) that "making your own materials is easy and promotes meaningful and significant learning." Research has shown, however, that the production of innovative materials is a process requiring specific training (Rowel \& Ebbers, 2004; Krajcik et al., 2008). We are in no doubt that teachers intending to make their own materials face various difficulties, and it is thus important to support teaching staff with tried and trusted material that can aid them to design, develop and evaluate their own initiatives (Cañal et al., 2005). We believe, too, that this methodological approach should feature in both initial and in-service training programmes, not least because it promotes the teacher's professional development as much as it stimulates meaningful learning on the part of the pupils by making the teaching immediate to their context (Mckenney \& Voogt, 2012).

With regard to the final research question - To what extent do teaching materials constrain teaching style? - we can say that there is a clear consensus among teachers that self-produced materials, unlike the textbook, have a positive influence on development and on the processes of teaching in general.

In turn, the carrying out of the case studies also provided a valuable source of information to enable the assessment of the influence of materials on teaching. In this instance, we were able to compare the data obtained from the preceding analysis of the methodological foundations of the two sets of materials according to the Teaching Material Quality Index (TMQI) with the observational data drawn from the corresponding case studies, which provided insights into how materials and teaching were interlinked, without making any generalised claims of causal relationships. Hence, in the first case study, which received a high TMQI rating, it should be noted that the greater part of the decisions about the syllabus were taken by the publishing team, with the scope of the teacher limited to occasional modifications to take account of the pupils' input and interests. Further, such modifications tend to disrupt the premises on which the book is based and increase uncertainty among the teacher, the pupils and their families. By contrast, in the second case study, which received a low TMQI rating, the teacher, as the creator of her own material, was able to mould the material for her proposed project to the immediate surroundings and the interests of the pupils, without depending on any significant outside interests. Any adjustments that she makes to this package are likely to enhance her own, the parents' and her pupils' satisfaction.

Finally, we would underline that the important thing is not to replace one set of materials for another, swapping textbooks for teacher-produced materials or vice versa. Rather, we advocate for fostering educational principles which drive the development of teacher-held beliefs towards the goal of 
improving classroom practice. To this end, we would recommend further case study-based research to explore the design, execution and evaluation of educational materials.

\section{Acknowledgements}

This paper forms part of the Project for Excellence in Research: ¿Cómo se realiza la enseñanza sobre la realidad social y natural en las aulas de Educación Infantil y Primaria de Andalucía? Estudio de las estrategias didácticas y propuestas de mejora. SEJ-5219 (2010-2014) and the I+D Project: ¿Cómo mejorar la enseñanza elemental sobre el medio?: Análisis del currículo, los materiales y la práctica docente. EDU2009-12760EDUC (2009-2012).

We would like to express our gratitude to the participating Schools for Nursery \& Primary Education "Virgen del Carmen" (Punta Umbría, Huelva) and "El Puntal" (Bellavista, Huelva), especially to those teachers who agreed to take part.

\section{References}

Adelman, N., Panton, K., Eagle, W., \& Hargreaves, A. (2003). Una carrera contra el reloj. Tiempo para la enseñanza y el aprendizaje en la reforma escolar. Madrid: Akal.

Apple, M. (1986). Teachers and Texts: A Political Economy of Class and Gender Relations in Education. London: Routledge.

Area, M. (1987). Medios de enseñanza y toma de decisiones del profesor. Un estudio cualitativo de casos. Unpublished Doctoral Thesis, Universidad de La Laguna (España).

Arias, A.Mª Bismack, A., Davis, E., \& Palincsar, A. (2016). Interacting with a Suite of Educative Features: Elementary Science Teachers' Use of Educative Curriculum Materials. Journal of Research in Science Teaching, 53(3), 422-449. https://doi.org/10.1002/tea.21250

Atienza, E., \& Van Dijk, T. (2010). Identidad social e ideología en libros de texto españoles de Ciencias Sociales. Revista de Educación, 353, 67-106.

Bardin, L. (1996). Análisis de contenido (2a Ed.). Madrid: Akal.

Bayona, B. (2009). Reflexiones y propuestas sobre la politica de gratuidad de los libros de texto en España. Asociación Nacional de Editores de Libros y Materiales de Enseñanza. Available at: http://www.anele.org/pdf/0902reflexionesypropuestas.pdf 
Campagno, L., Castillo, S., \& Ferrero, S. (2009). El lugar del libro de texto para la enseñanza de las ciencias sociales en el tercer ciclo de E.G.B., en contextos sociales adversos. Conference paper delivered at Cuarto Congreso Nacional y Segundo Internacional de Investigación Educativa. Universidad Nacional del Comahue, Facultad de Ciencias de la Educación, Rio Negro Argentina, 21, 22 y 23 de octubre de 2009. Available at: http://trabajodecampojuegaalwiki.wikispaces.com/file/view/Libros+de+texto.pdf

Cañal, P., Pozuelos, F.J., \& Travé, G. (2005). Proyecto curricular Investigando nuestro mundo (pp. 6-12). Sevilla: Díada.

Cañal, P., Travé, G., \& Pozuelos, F.J. (2011). Análisis de obstáculos y dificultades de profesores y estudiantes en la utilización de enfoques de investigación escolar. Investigación en la escuela, 73, 5-26.

Carvalho, G., Silva, R., \& Clément, P. (2007). Historical analysis of Portuguese primary school textbooks (1920-2005) on the topic of digestion. International Journal of Science Education, 29(2), 173-193. https://doi.org/10.1080/09500690600739340

Charalambous, C., \& Hill, H. (2012). Teacher Knowledge, Curriculum Materials, and Quality of Instruction: Unpacking a Complex Relationship. Journal of Curriculum Studies, 44(4), 443-466. https://doi.org/10.1080/00220272.2011.650215

Chong, I. (2016). Pedagogical Design Capacity and Underlying Knowledge Base of Curriculum Materials Use of a Hong Kong English Teacher. English Language Teaching, 9(5), 85-97. https://doi.org/10.5539/elt.v9n5p85

Fernández Reiris, A. (2003). La función del libro de texto en el aula. Hegemonía y control del curriculum. Unpublished doctoral thesis, Universidad de Valencia (España).

Figg, C., \& Jaipal-Jamani, K. (2011). Exploring Teacher Knowledge and Actions Supporting Technology-Enhanced Teaching in Elementary Schools: Two Approaches by Pre-Service Teachers. Australasian Journal of Educational Technology, 27(7), 1227-1246. https://doi.org/10.14742/ajet.914

Forbes, C., \& Davis, E. (2010). Curriculum design for inquiry: Preservice elementary teachers' mobilization and adaptation of science curriculum materials. Journal of Research in Science Teacbing, 47(7), 820-839. https://doi.org/10.1002/tea.20379

García-Prieto, F.J., López, F.J., \& Correa, C. (2013). ¿Qué quiero ser de mayor? Trabajando las profesiones en el aula de infantil. Cuadernos de Pedagogía, 432, 58-60.

Green, R.A. (2014). The Delphi Technique in Educational Research (pp. 1-8). Thousand Oaks, The United States: SAGE Open. https://doi.org/10.1177/2158244014529773 
Grossman, P., \& Thompson, C. (2008). Learning from Curriculum Materials: Scaffolds for New Teachers?. Teaching and Teacher Education: An International Journal of Research and Studies, 24(8), 20142026. https://doi.org/10.1016/j.tate.2008.05.002

Güemes, R.Ma. (2001). Algunas investigaciones en torno al uso de los libros de texto en las aulas. Primeras Noticias. Comunicación y pedagogía: Nuevas tecnologías y recursos didácticos, 20(175), 76-83.

Hargreaves, A. (1996). Profesorado, cultura y posmodernidad. Cambian los tiempos, cambia el profesorado. Madrid: Morata.

Henning, H., Hlawatsch, S., \& Lucken, M. (2007). Enactment of a Geoscience Curriculum by Using Innovative Curriculum Materials: An Exploratory Case Study. Journal of Geography Education, 35(4), 286-306.

Hernández, A. (2012). ¿Cómo tratan los libros de texto de bachillerato la crisis económica? Investigación en la Escuela, 76, 51-64.

Issitt, J. (2004). Reflections on the study of textbooks. History of Education, 33(6), 683-697. https://doi.org/10.1080/0046760042000277834

Kasim, Y. (2008). A case study on the use of materials by classroom teachers. Educational Sciences: Theory and Practice, 8(1), 305-322.

Krajcik, J., McNeill, K., \& Reiser, B. (2008). Learning-Goals-Driven Design Model: Developing Curriculum Materials that Align with National Standards and Incorporate Project-Based Pedagogy. Science Education, 92(1), 1-32. https://doi.org/10.1002/sce.20240

Loeb, H., Knapp, M.S., \& Elfers, A.M. (2008). Teachers' response to standards-based reform: Probing reform assumptions in Washington State. Education Policy Analysis Archives, 16(8), 1-32. Available at: http://epaa.asu.edu/epaa/v16n8 https://doi.org/10.14507/epaa.v16n9.2008

López Hernández, A. (2007). Libros de texto y profesionalidad docente, Avances en Supervisión Educativa. Revista de la Asociación de Inspectores de Educación de España, 6,1,13. Available at: http://www.adide.org/revista/index.php/ase/article/view/282/244

Maestro, P. (2002). Libros escolares y currículum. Del reinado de los libros de texto a las nuevas alternativas del libro escolar. Revista de Teoría y Didáctica de las Ciencias Sociales, 7, 25-52.

Martínez-Rizo, F. (2012). Procedimientos para el estudio de las prácticas docentes. Revisión de la literatura. Relieve, 18(1), art.1. Available at: http://www.uv.es/RELIEVE/v18n1/RELIEVEv18n1 1.htm

Mckenney, S., \& Voogt, J. (2012). Teacher Design of Technology for Emergent Literacy: An Explorative Feasibility Study. Australasian Journal of Early Childhood, 37(1), 4-12. 
McKernan, J. (1991). Curriculum Action Research: a Handbook of Methods and Resources for the Reflective Practitioner. London: Kogan Page Ltd.

Morcillo, V., \& Romero, D. (2013). ¡Estar en forma es genial!. Cuadernos de pedagogía, 432, 61-63.

Moulton, J. (1997). How do teachers use textbooks? A review of the research literature. Health and Human Resources Analysis for Africa Project. Technical Paper 74. Available at: http://textbookuse.pbworks.com/f/74textbooks.pdf

Paredes, J. (1999). Análisis etnográfico de los usos de recursos y materiales didácticos en educación primaria. Estudios de los casos de dos centros. Tesis doctoral inédita, Universidad Complutense de Madrid (España).

Peiró-Velert, C., Molina-Alventosa, P., Kirk, D., \& Devís-Devís, J. (2015). The Uses of Printed Curriculum Materials by Teachers during Instruction and the Social Construction of Pedagogic Discourse in Physical Education. Journal of Teaching in Physical Education, 34(1), 18-35. https://doi.org/10.1123/jtpe.2012-0157

Pérez Gómez, Á.I., \& Gimeno, J. (1994). Evaluación de un proceso de innovación educativa. Sevilla: Junta de Andalucía.

Pingel, F. (2010). Guide UNESCO pour l'analyse et révisión des manuels scolaires. Francia: UNESCO.

Pinto, L. (2007). Textbook publishing, textbooks, and democracy. A case study. Journal of Thought, 42(1-2), 99-121.

Pozuelos, F.J., Travé, G., \& Cañal, P. (2007). Acerca de cómo el profesorado de primaria concibe y experimenta los procesos de investigación escolar. Revista de Educación, 344, 403-423.

Pozuelos, F.J., Travé, G., \& Cañal, P. (2010). Inquiry-based teaching: teachers' conceptions, impediments and support. Teaching Education, 21(2), 131-142. https://doi.org/10.1080/10476210903494507

Reininger, J. (2010). My text: An alternative to traditional textbook. Computers in Human Behavior, 26, 119-121. https://doi.org/10.1016/j.chb.2009.09.004

Rodríguez, J. (2000). Os materiais curriculares impresos e a reforma educativa en Galicia. Unpublished doctoral thesis, Universidad de Santiago de Compostela (España).

Rowel, P., \& Ebbers, M. (2004). School Science Constrained: Print Experiences in Two Elementary Classrooms. Teaching \& Teacher Education: An International Journal of Research and Studies, 20(3), 217-230. https://doi.org/10.1016/j.tate.2004.02.006

Simons, H. (2009). Case Study Research in Practice. London: SAGE. https://doi.org/10.4135/9781446268322 
Sosniak, L., \& Stodolsky, S. (1993). Teachers and textbooks: Materials use for fourth-grade classrooms. The Elementary School Journal, 93(3), 249-275. https://doi.org/10.1086/461725

Soto, F. (2006). El libro de texto y la biblioteca escolar. La escuela del pasado y la del futuro. Revista TK, 18, 27-39.

Stenhouse, L. (1987). La investigación como base de la enseñanz̧a. Madrid: Morata.

Su, Y.S. (2007). Ideological Representations of Taiwan's History: An Analysis of Elementary Social Studies Textbooks, 1978-1995. Curriculum Inquiry, 37(3), 205-237. https://doi.org/10.1111/j.1467873X.2007.00383.x

Travé, G., \& Pozuelos, F.J. (2008). Consideraciones didácticas acerca de las líneas de investigación en materiales curriculares. A modo de presentación. Investigación en la Escuela, 65, 3-10.

Travé, G., Pozuelos, F.J., \& Cañal, P. (2006). Cómo enseñar investigando análisis de las percepciones de tres equipos docentes con diferentes grados de desarrollo profesional. Revista Iberoamericana de Educación, 39(5), 1-24. Available at: http://rieoei.org/1366.htm

Travé, G., Pozuelos, F.J., \& Cañal, P. (2016). Diseño de la investigación. En P. Cañal, G. Travé, F.J. Pozuelos, A. Criado y A. García (Coords), La enseñanza sobre el medio natural y social. Investigación y experiencias (pp. 23-34). Sevilla: Díada.

Travé, G., Pozuelos, FJ., Cañal, P., \& Rodríguez, F.P. (2016). Validación de un instrumento de análisis de materiales (AMADE). In P. Cañal, G. Travé \& F.J. Pozuelos et al. (Coords.), La enseñanza sobre el Medio Naturaly Social. Investigación y experiencias (pp. 97-114). Sevilla: Díada.

Varela, J. (2008). El libro de texto ante la incorporación de las TIC a la enseñanza. Available at: http://federacioneditores.org/img/documentos/Los TIC enEnsenanza.pdf

Vargas, J.C., \& Chavarría, A. (2011). El libro de texto: Los profesores de hoy. Ensayos Pedagógicos, 1(1), 133-143.

Winzenried, A., Dalgarno, B., \& Tinkler, J. (2010). The Interactive Whiteboard: A Transitional Technology Supporting Diverse Teaching Practices. Australasian Journal of Educational Technology, 26(special issue 4), 534-552. https://doi.org/10.14742/ajet.1071

Yelas, J., \& Engels, P. (2010). Project ACTIVate: Innovations from New Zealand. Australasian Journal of Educational Technology, 26(4), 432-446. https://doi.org/10.14742/ajet.1063

Zahorik, J. (1991). Teaching style and textbooks. Teaching and Teacher Education, 7(2), 185-196. https://doi.org/10.1016/0742-051X(91)90026-L 
Zembylas, M. (2004). Emotion Metaphors and Emotional Labor in Science Teaching. Science Education, 88(3), 301-324. https://doi.org/10.1002/sce.10116

Zenobi, V. (2012). Los profesores de Geografía, la innovación de la enseñanza y su profesionalización: el lugar de los materiales curriculares. Conference paper presented at I Encuentro Iberoamericano de Investigación en Didáctica de las Ciencias Sociales. Panel La Enseñanza y el Aprendizaje de la Geografía y la Historia. Universidad de Antioquia, Medellín, Colombia, 6 y 7 de diciembre de 2012.

\section{Annex}

\begin{tabular}{|c|c|c|c|c|c|c|c|c|c|c|c|c|c|c|c|c|c|c|c|}
\hline & 2 & 3 & 5 & 7 & 8 & y & 14 & 17 & 23 & $25 a$ & $25 b$ & $25 c$ & $25 d$ & 30 & $31 \mathrm{a}$ & $1 b$ & $31 c$ & $1 d$ & \\
\hline 21 & & 9.5 & 5.9 & 2.7 & 1.2 & 18.8 & & 16.7 & 10.5 & & & & & 2.9 & & & 5.0 & & \\
\hline & 49.2 & 49.2 & 31.1 & 21.3 & 6 & 30.6 & 8.3 & 9.5 & 29.7 & 3.0 & 18.8 & 54.0 & 5 & 26.9 & 41.7 & 3.2 & 48.4 & .2 & \\
\hline & & & & & 7.2 & & & 2 & & & & & & & & & & & \\
\hline & & & 455 & 40.2 & 39.6 & 22.8 & 9.4 & 29.1 & .7 & 28.2 & 29.4 & 25.7 & 22.2 & ) & & 20.7 & 38.4 & & \\
\hline & & 2. & & 35 & 53 & 25.8 & & 4.3 & 22 & 7.5 & 7.4 & 7 & 6.8 & & & 5.0 & & & \\
\hline & & & & 75.2 & 92.6 & 48.6 & & 3.4 & 58 & 35.7 & 36.8 & 33.0 & 29.0 & 69.6 & & 25.7 & 45.5 & 65 & \\
\hline & & & & & & 2.5 & & & & & & & & & & & 2.48 & & \\
\hline & 670 & 6887 & .611 & \begin{tabular}{|l}
.818 \\
\end{tabular} & .662 & .076 & .682 & .767 & .939 & .813 & .794 & .768 & .816 & .737 & .855 & .686 & .703 & .758 & \\
\hline ost & 0.5 & 0.5 & 1.0 & 0.8 & 0.2 & & 0.2 & 0.5 & 1.2 & 1.4 & 1.5 & 1.4 & 1.6 & 0.6 &.$J$ & .0 & 1.2 & & \\
\hline
\end{tabular}

\begin{tabular}{|c|c|c|c|c|c|c|c|c|c|c|c|c|c|c|c|c|}
\hline & 32 & 41 & 43 & 44 & 45 & $16 a$ & $46 b$ & $46 c$ & 46d & $46 \mathrm{e}$ & $46 f$ & 49 & $50 a$ & $50 \mathrm{~b}$ & 50c & 50d \\
\hline R1 & 1.2 & 31.1 & 0.5 & 5.1 & 4.2 & 3.8 & 1.6 & 8.3 & 3.1 & 4.6 & 0.2 & 12.4 & 0.6 & 0.6 & 0.8 & \\
\hline 2 & 20.0 & 42.3 & 15.6 & 31.2 & 43.9 & 22.8 & 19.2 & 28.6 & 20 & 34.4 & 2.3 & 61.6 & 10.5 & 10.3 & 8.8 & 12.3 \\
\hline & & & & & & & & & 23.1 & & & & & & 9.6 & \\
\hline & & 19.7 & 51 & 45. & 42. & 43.1 & 51.9 & 42 & & 41. & & 22.1 & 9 & 46.0 & 41.6 & 2. \\
\hline & & 5.7 & & 18. & 8. & 29 & 26.4 & 19.6 & 30.7 & 1 & 5 & 3.0 & 38.0 & 42.3 & & 43. \\
\hline & & & & & 50.7 & & 78.3 & & 2 & 59.3 & 8.6 & 25.1 & 87.9 & 88.3 & 89.1 & \\
\hline & 3.09 & 2.00 & 3.16 & 2.3 & 2.5 & & 3.04 & 2.74 & 3.04 & 2.74 & & 2.16 & 3.27 & 3.31 & 3.38 & 3.3 \\
\hline STAN DEV & 1.01 & .863 & .691 & .885 & .711 & .825 & .724 & .871 & .801 & .809 & .841 & .667 & .666 & .677 & .680 & 71 \\
\hline Lost & 3.2 & 1.3 & 0.1 & 0.8 & 1.3 & 1.3 & 0.8 & 1.3 & 1.6 & 1.7 & 88.9 & 0.8 & 0.9 & 0.8 & 1.3 & \\
\hline
\end{tabular}

Table 2. General results from questionnaire 


\section{Versión en español}

Título: Cómo el profesorado diseña y desarrolla en la práctica materiales curriculares para mejorar la enseñanza

\section{Resumen}

Objeto: Analizar las concepciones del profesorado sobre los materiales curriculares, su diseño y desarrollo en la práctica, específicamente indagando en las posibilidades que la elaboración de materiales curriculares alternativos encierra para su desarrollo profesional.

Diseño/metodología/enfoque: Metodología de carácter integrado basada en la administración de un cuestionario a una muestra de 864 docentes y la realización de dos estudios de casos en aulas de Educación Infantil donde se emplearon entrevistas, observaciones, diarios y grabaciones.

Aportaciones y resultados: Los resultados confirman la presencia mayoritaria de los libros de texto en los centros de Educación Infantil y Primaria andaluces, como así el papel determinante que tienen en la definición de la práctica educativa, incluso en aquellos casos en los que se intenta complementar desde perspectivas de innovación educativa. El profesorado, sin embargo, pone en valor los beneficios de los materiales de elaboración propia, no solo a la hora de fomentar el aprendizaje significativo sino para su desarrollo profesional, si bien representa una opción no exenta de obstáculos y dificultades.

Implicaciones prácticas: Los resultados de investigación avalan la necesidad de apoyar a los equipos docentes comprometidos con la elaboración propia de materiales curriculares.

Implicaciones sociales: El marco de acción relativo a la política de gratuidad de libros de texto en la comunidad debería ser revisado a la luz de las conclusiones de la investigación.

Originalidad / Valor añadido: La investigación contribuye a visibilizar una de las paradojas existentes en nuestro sistema educativo relacionada con el uso de los materiales curriculares: mientras el profesorado utiliza los libros de texto de forma masiva considera que éstos no son los materiales más óptimos para contribuir a la mejora de los procesos de enseñanza/ aprendizaje.

Palabras clave: Concepciones del profesor, Estudio de casos, Libros de texto, Elaboración de materiales, Práctica docente 
Códigos JEL: I21

\section{Introducción}

El estudio de las concepciones y prácticas del profesorado acerca de la utilización de los materiales curriculares (libros de texto y materiales de elaboración docente) representa un campo de investigación aún en expansión. Si comparamos su producción con la investigación centrada en el análisis de los aspectos ideológicos, epistemológicos, axiológicos, psicológicos y didácticos de los materiales, podríamos calificarla cuanto menos de minoritaria (Apple 1986; Carvalho, Silva \& Ferrero, 2007; Pinto, 2007; Su, 2007; Travé \& Pozuelos, 2008; Atienza \& Van Dijk, 2010; Hernández, 2012).

El análisis de las declaraciones del profesorado sobre el uso de los materiales se ha basado en el empleo de metodologías cuantitativas y cualitativas, mediante la administración de cuestionarios y entrevistas (Kasim, 2008; Forbes \& Davis, 2010; Peiró-Velert, Molina-Alventosa, Kirk \& Devís-Devís, 2015). Estos trabajos han logrado una primera aproximación al pensamiento y la práctica docente en el aula (Pérez Gómez \& Gimeno, 1994; Rodríguez, 2000; López Hernández, 2007), si bien no debemos olvidar que constituyen acercamientos parciales.

Asimismo, desde el punto de vista cualitativo, los estudio de casos facilitan el conocimiento del aula en su profundidad y constituye una línea de investigación de progresivo impacto científico (Area, 1987; Zahorik, 1991; Sosniak \& Stodolsky, 1993; Vargas \& Chavarria, 2011). Esta metodología permite el análisis conjunto de los materiales de desarrollo curricular y de las percepciones y prácticas del profesorado cuando utiliza los recursos didácticos (Henning, Hlawatsch \& Lucken, 2007; Krajcik, Mcneill \& Reiser, 2008; Charalambous \& Hill, 2012; Arias, Bismack, Davis \& Palincsar, 2016; Chong, 2016). Entre las conclusiones de estos estudios y, por su interés para este trabajo, se ha demostrado la existencia de dos modelos de uso de los materiales: uno, de dependencia profesional del libro de texto basado en una concepción tradicional de la enseñanza; y, otro, de autonomía profesional respecto al texto de índole crítico y reflexivo (Güemes, 2001). Se ha constatado, asimismo, que los profesores que adoptan modelos de desarrollo profesional innovadores están más predispuestos a emplear recursos y materiales didácticos heterogéneos o, al menos, un uso menos convencional de los manuales (Paredes, 1999). 
Investigaciones más recientes, están incidiendo en otros aspectos relacionados con la utilización de materiales variados -sobre todo virtuales- (Winzenried, Dalgarno \& Tinkler, 2010; Yelas, \& Engels, 2010; Figg \& Jaipal-Jamani, 2011; Mckenney \& Voogt, 2012), así como en la importancia de las concepciones y prácticas del profesorado en formación inicial y permanente. Estas investigaciones han puesto de manifiesto, entre otros, los resultados siguientes:

- que "todos los profesores del estudio, incluso aquéllos que no habían adoptado un texto único, tenían como referencia principal para la planificación a los libros de texto" (Fernández Reiris, 2003, pp. 609);

- el excesivo tiempo que los profesores noveles dedican a la búsqueda de manuales y el poder que poseen estos para cambiar las concepciones y prácticas docentes (Grossman \& Thompson, 2008); y

- que los materiales curriculares favorecen el desarrollo profesional y el aprendizaje del alumnado, en la medida que ofrecen propuestas adaptables a diferentes contextos escolares y finalidades educativas, así como a su actualización temática y didáctica (Zenobi, 2012).

En nuestro caso, se han desarrollado varios trabajos con la finalidad de analizar las concepciones y prácticas del profesorado en relación con los procesos de investigación escolar, entre otros aspectos, relacionados con el uso de materiales curriculares (Travé, Pozuelos \& Cañal, 2006; Pozuelos, Travé \& Cañal, 2007; Pozuelos, Travé \& Cañal, 2010). Entre las conclusiones, destaca el hallazgo de una progresión en las concepciones profesionales que avanza, según el nivel de desarrollo docente, desde propuestas escasamente fundamentadas en la aplicación rígida del manual o material elaborado, hasta otras -de carácter complejo- que integran una amplia gama de materiales y recursos de elaboración propia estructurados en función de un proyecto de trabajo por investigación escolar.

Se presenta, en esta ocasión, una investigación integrada que se estructura en función de dos estudios, uno, de carácter extensivo, a partir de un cuestionario; y otro, que complementa al anterior con un trabajo intensivo, basado en dos estudios de casos. La triangulación de ambos puntos de vista tiene por objetivo conocer en profundidad cómo el profesorado diseña y desarrolla los materiales en su práctica docente. Específicamente, las preguntas que guiaron la investigación fueron las siguientes:

- ¿Qué materiales se emplean en clase y por qué se seleccionan? 
- ¿Qué papel desempeñan los materiales en relación a los elementos curriculares y cómo se elaboran?

- ¿En qué proporción condicionan los materiales la forma de enseñar?

\section{Diseño y metolodogía}

La metodología de este trabajo es de carácter integrada, basándose -como se ha comentado- en la administración de un cuestionario a una muestra de docentes y la realización de dos estudios de casos. Loeb, Knapp y Elfers (2008), en este sentido, consideran que este tipo de estudios facilitan un alto grado de complementariedad.

La selección de la muestra del cuestionario ha requerido un muestreo aleatorio por conglomerados geográficos en las ocho provincias andaluzas. El tamaño del centro escolar, por sus particularidades de funcionamiento, ha influido también en la selección de los centros (grandes pequeños y con líneas incompletas). Una vez elegidos, se les proporcionaron catorce cuestionarios a cada uno de los directores-as para que los repartieran a los docentes que impartieran enseñanzas socionaturales; y que hubiera un reparto equilibrado entre las dos etapas educativas (proporcional al número de enseñantes) y porcentualmente entre las dos etapas educativas. Este procedimiento ha permitido obtener información de un total de noventa y cuatro centros de Educación Infantil y Primaria de toda Andalucía.

En cuanto a los estudios de casos, se utilizan para conocer en profundidad el estado de la práctica docente en relación a la utilización de los materiales curriculares. Simons (2011, pp. 42) considera, en este sentido, que "la finalidad primordial es generar una comprensión exhaustiva de un tema determinado". Los estudios de caso pertenecen a la línea de investigación-acción colaborativa (Mckernan, 1991). Los criterios de selección de los estudios de casos se establecieron siguiendo el interés de los equipos docentes por la innovación educativa, mantener una duración de un curso escolar, la participación voluntaria de los docentes, así como la oportuna negociación y difusión de los datos.

Las dos escuelas elegidas, de entre todas aquellas que expresaron su interés por participar, no sólo cumplían los criterios anteriores, sino que se eligieron además porque representaban contextos educativos distintos, lo que ha permitido realizar comparaciones relevantes. 


\subsection{Instrumentos de investigación}

El instrumento utilizado para la obtención de la información ha sido una escala tipo Likert con cuatro opciones de respuesta que van desde "totalmente de acuerdo" a "totalmente en desacuerdo" a los que hemos añadido una casilla abierta de carácter optativo para que los encuestados pudieran incluir "aclaraciones o dudas". Los 51 ítems del cuestionario se agruparon en las categorías: proceso de elaboración y evaluación de los materiales, aspectos epistemológicos, axiológicos, psicológicos, elementos curriculares de los materiales y relación de los materiales con el currículum. La escala incluye además una serie de cuestiones de carácter ilustrativo en la que nos hemos interesado por los datos personales, académicos y profesionales de cada participante. El cuestionario se administró en la Comunidad Autónoma de Andalucía (España), que contaba en el momento de su administración con un total de 50,576 profesores-as de centros públicos de Infantil y Primaria. Se recibieron 864 cuestionarios cumplimentados adecuadamente.

Los instrumentos utilizados en los dos casos, que pasamos a caracterizar brevemente, han sido comunes y variados con la finalidad de reconstruir los aspectos de la práctica docente para facilitar un análisis detallado.

Se han realizado diversas entrevistas a lo largo del proceso que han seguido un guión semiestructurado al objeto de profundizar en las respuestas. Asimismo, se ha utilizado un cuestionario complementario al del estudio cuantitativo: Cuestionario F. para caracterizar la enseñanza relativa al medio socionatural (Travé, Pozuelos, Cañal \& Rodríguez, 2016). Además, se han analizado los documentos de los proyectos educativos de ambas docentes. Los diarios de las maestras, sus memorandums (notas de campo) y el diario del investigador han permitido obtener datos de las observaciones directas. Se han realizado grabaciones de vídeo en siete sesiones de clase y salidas de trabajo a la localidad. El análisis de documentos, realizado en torno a los proyectos educativos de ambas docentes, siguió un proceso de análisis documental según las orientaciones de Bardin (1996). El análisis de los resultados requirió la transcripción y codificación de todos los registros. Posteriormente los datos de los distintos instrumentos se han sometido a un proceso de triangulación (Martínez- Rizo, 2012).

El tratamiento de datos de los instrumentos de ambos trabajos ha requerido el empleo de diversas técnicas y procedimientos. Los datos del cuestionario se analizaron con el paquete informático SPSS en su versión 16 y con el programa SPAD en su versión 4.5. Los resultados correspondientes a cada pregunta de las distintas categorías del cuestionario se presentan divididos según las opciones elegidas por el profesorado de la muestra en la escala Likert. La suma de las respuestas R1 y R2 indica 
desacuerdo total o parcial, mientras que la adición de R3 y R4 expresa el conjunto de las opiniones de acuerdo parcial o total.

El análisis de los datos de los estudios de caso se efectuó mediante un proceso de categorización y, debido a su volumen y complejidad, procesado con el programa ATLAS.ti en su versión 6.2. Las citas de contenidos procedentes de este análisis se expresan mediante la nomenclatura que se observa en el siguiente ejemplo: "Las tareas tienen una visión muy práctica y los alumnos están más motivados" (4:37, 248:250, maestra 2). De tal manera, los códigos utilizados tienen el siguiente significado: 4:37 = número de recurso (documento): número de cita en dicho documento: 248:250 = párrafo donde se inicia la cita: párrafo donde termina la cita. Maestra 2: docente que realiza la afirmación. El tratamiento de los datos se efectuó de acuerdo con lo expresado en la Tabla 1.

\begin{tabular}{|c|c|c|c|c|}
\hline Categorías & Preguntas & Contenidos & Objetivos & $\begin{array}{l}\text { Instrumentos de } \\
\text { investigación }\end{array}$ \\
\hline $\begin{array}{l}\text { Categoría } 1 . \\
\text { Materiales para la } \\
\text { enseñanza: libro } \\
\text { de texto versus } \\
\text { material de } \\
\text { elaboración propia }\end{array}$ & $\begin{array}{l}\text { ¿Qué materiales se } \\
\text { emplean en clase? } \\
\text { ¿Por qué se } \\
\text { seleccionan los } \\
\text { materiales } \\
\text { curriculares? }\end{array}$ & $\begin{array}{l}\text {-Tipología de materiales } \\
\text { curriculares en uso. } \\
\text {-Valoración del libro de } \\
\text { texto y de los materiales de } \\
\text { elaboración propia. } \\
\text {-Causas para la selección } \\
\text { de los materiales. }\end{array}$ & $\begin{array}{l}\text {-Describir el tipo de } \\
\text { materiales utilizado: } \\
\text { libro de texto versus } \\
\text { material elaboración } \\
\text { propia. } \\
\text {-Conocer las valoraciones } \\
\text { del profesorado en torno a } \\
\text { los diferentes materiales. } \\
\text {-Analizar los argumentos } \\
\text { para la selección de los } \\
\text { materiales. }\end{array}$ & \multirow{3}{*}{$\begin{array}{l}\text {-Entrevista } \\
\text {-Cuestionario F } \\
\text {-Diario maestra } \\
\text {-Diario } \\
\text { investigador } \\
\text {-Memorándum } \\
\text { maestra } \\
\text {-Análisis de } \\
\text { documentos (Proyecto } \\
\text { educativo) } \\
\text {-Grabación y } \\
\text { transcripción de vídeo } \\
\text {-Cuestionario general } \\
\text { (muestra regional) }\end{array}$} \\
\hline $\begin{array}{l}\text { Categoría } 2 . \\
\text { Papel de los } \\
\text { materiales } \\
\text { curriculares en los } \\
\text { procesos de } \\
\text { enseñanza }\end{array}$ & $\begin{array}{l}\text { ¿Qué papel } \\
\text { desempeñan los } \\
\text { materiales en } \\
\text { relación a los } \\
\text { elementos } \\
\text { curriculares? } \\
\text { ¿Cómo se elaboran } \\
\text { los materiales } \\
\text { curriculares? }\end{array}$ & $\begin{array}{l}\text {-Materiales y elementos } \\
\text { curriculares: competencias } \\
\text { clave, contenidos, } \\
\text { metodología, actividades y } \\
\text { evaluación. } \\
\text {-Adaptación del libro de } \\
\text { texto. } \\
\text {-Planificación de } \\
\text { materiales de elaboración } \\
\text { propia. }\end{array}$ & $\begin{array}{l}\text {-Describir el papel de los } \\
\text { materiales en relación al } \\
\text { resto de elementos } \\
\text { curriculares. } \\
\text {-Indagar en los procesos } \\
\text { de adaptación del libro de } \\
\text { texto y planificación de los } \\
\text { materiales de elaboración } \\
\text { propia. }\end{array}$ & \\
\hline $\begin{array}{l}\text { Categoría } 3 . \\
\text { Influencia de los } \\
\text { materiales } \\
\text { curriculares en el } \\
\text { modelo didáctico } \\
\text { del profesorado }\end{array}$ & $\begin{array}{l}\text { ¿En qué } \\
\text { proporción } \\
\text { condicionan los } \\
\text { materiales la forma } \\
\text { de enseñar? }\end{array}$ & $\begin{array}{l}\text {-Influencia de los } \\
\text { materiales en el modo de } \\
\text { enseñar. }\end{array}$ & $\begin{array}{l}\text {-Examinar la relación } \\
\text { entre los materiales y el } \\
\text { modelo didáctico. }\end{array}$ & \\
\hline
\end{tabular}

Tabla 1. Categorías, contenidos y cuestiones relacionados con el estudio del cuestionario y los estudios de caso

Seguidamente se caracterizan los contextos en los que se desarrollaron los estudios de casos, y de detalla el procedimiento seguido para el análisis de los materiales curriculares empleados por ambas docentes. 


\subsection{Descripción de las aulas donde se implementaron los estudios de casos y análisis de los materiales curriculares utilizados}

La caracterización de las aulas en las que se desarrollaron los estudios de casos responde a la finalidad de contextualizar las declaraciones de las docentes, contribuyendo asimismo a la comprensión de los fenómenos objeto de estudio.

Las participantes son dos maestras de Educación Infantil de dos escuelas públicas de la provincia de Huelva (España). El primer caso trata de una clase de tres años y una profesora que se inicia en procesos de innovación curricular. El segundo caso pertenece a una clase de cuatro años de una localidad costera y la maestra posee una dilatada experiencia innovadora.

El procedimiento de investigación se dividió en dos etapas. En la primera se realizó la toma de contacto, la negociación y la planificación del proyecto de estudio de casos, en la que se acordó que las maestras asumirían las funciones siguientes: a) convenir los objetivos didácticos; b) participar activamente en el diseño o adaptación de los materiales curriculares de la clase; c) poner en práctica las propuestas descritas y desarrolladas en el marco de la colaboración en la investigación; d) utilizar los instrumentos de investigación que previamente han sido negociados, e) participar en la revisión de las transcripciones y los datos de la investigación; y, finalmente gozar de total confidencialidad y anonimato con respecto a sus contribuciones.

La segunda etapa se refiere al desarrollo de los respectivos módulos de enseñanza. La profesora del primer caso adaptó la unidad didáctica: "El cuentacuentos. Las profesiones", del libro de la editorial Edelvives de tres años, para utilizarlo como material curricular del módulo de enseñanza. La profesora del segundo caso diseñó un material de elaboración propia sobre el tema de la alimentación saludable con la ayuda de un banco de recursos actualizados. Ambas experiencias de aula se pueden consultar en García-Prieto, López y Correa (2013) y Morcillo y Romero (2013).

La realización de los estudios de casos se simultaneó con un análisis de los materiales curriculares de ambas maestras, a partir de un instrumento que se detallará seguidamente.

La premisa que guió el estudio específico de los materiales que vertebraron los procesos didácticos obedece a la consideración de que la relación existente entre la calidad de los materiales curriculares, el desarrollo profesional del profesorado y la práctica de aula es incuestionable (Pingel, 2010; Cañal, Travé \& Pozuelos, 2011); si bien no debe entenderse de forma mecánica y simplista. Así, un buen material no siempre genera aprendizajes relevantes cuando es utilizado por docentes con escaso desarrollo 
profesional y, viceversa, mediocres textos escolares en manos de docentes con altas cotas de profesionalidad consiguen resultados óptimos. Sin embargo, el conocimiento de la calidad de los materiales empleados en el aula determina considerablemente la práctica educativa.

En los estudios de casos que se examinan en este artículo, se ha procedido al análisis de los materiales usados por ambas maestras, al objeto de obtener evidencias de la calidad de los materiales empleados. El instrumento usado para contrastar ambas producciones didácticas ha sido la Guía de Análisis de Materiales y Desarrollo de la Enseñanza (AMADE) (Travé, Pozuelos, Cañal \& Rodríguez, 2016). Su estructura se organiza en función de seis dimensiones referidas a los siguientes elementos:

- Aspectos epistemológicos del material curricular;

- Aspectos axiológicos.

- Aspectos psicológicos: tipo de aprendizaje, función de los conocimientos previos;

- Elementos curriculares: competencias clave, objetivos, contenidos (concepción, organización y relación con el medio), metodología, actividades (concepción, tipología y secuencia) y evaluación;

- Diseño de la enseñanza y

- Desarrollo profesional.

Los indicadores del tratamiento de datos se distribuyen en función de una hipótesis de progresión del pensamiento y la práctica docente en la enseñanza del medio social y natural, de la que se extrajo previamente la respuesta experta (RE) mediante la técnica delphi (Green, 2014), con la participación de siete profesores de distintas universidades españolas y ocho maestros en ejercicio. Los indicadores de análisis conforman los niveles de concepciones y prácticas del profesorado siguientes:

- Indicador A, cercanos al modelo didáctico basado en la investigación escolar, de donde se extrajo la respuesta experta (valor 0$)$,

- Indicador B, relacionados con los modelos didácticos de transición: tecnológico y espontaneísta (valor 1),

- Indicador C, próximos a los enfoques transmisivos - convencionales (valor 2);

- Indicador D, vinculados con propuestas distintas o similares a las descritas (valores $0,1,2,3$ en función del grado de sintonía con los indicadores anteriores A, B, C o D respectivamente).

El Índice de Calidad Didáctica del Material (ICDM) se calcula siguiendo las orientaciones de Travé, Pozuelos y Cañal (2016), mediante la obtención de la media de los valores absolutos de los indicadores 
de cada dimensión. La mínima distancia de los indicadores (respuesta experta, valor 0) implicaría un índice alto de calidad didáctica del material, mientras que la máxima distancia entre ellos supondría un índice bajo. La determinación del índice de calidad didáctica del material, se consigue siguiendo la fórmula, ICDM = 1 - / 3. Los resultados comparativos del análisis del Índice de Calidad Didáctica del Material de ambas maestras se presentan en apartado de resultados.

\section{Resultados}

\subsection{Perfil personal y profesional del profesorado participante en el cuestionario}

A continuación presentamos los resultados de las variables ilustrativas del cuestionario remitido por los 864 docentes andaluces de Educación Infantil y Primaria, permitiendo establecer un perfil extensivo que a su vez contextualice los resultados del análisis de las categorías que se presentará en los epígrafes subsiguientes.

La edad media de la muestra es de cuarenta y tres años y, el intervalo de treinta y uno a treinta y cinco años, el más numeroso (20.7\%). Por sexo, el profesorado se reparte en tres cuartas partes de mujeres (74.9\%) y un $25.1 \%$ de hombres. Respecto a la localización de los centros, las ocho provincias andaluzas están representadas con al menos el 10\% de los cuestionarios, aunque, como hemos mencionado con anterioridad, nos interesaba especialmente la representación de todas las comarcas andaluzas. El nivel educativo que imparte el profesorado corresponde a Educación Primaria en más de las tres cuartas partes (77.9\%), repartiéndose aproximadamente con un $19 \%$ de media en cada uno de los tres ciclos de esta etapa y el $22.1 \%$ en Educación Infantil.

Más de la mitad del profesorado participante realiza funciones de tutoría (54.7\%) y el 17.7\% la coordinación de ciclo. La edad media de experiencia docente es de 19.9 años, con un sector mayoritario (25.8\% de la muestra) situado en la franja de veintiuno a treinta años. La docencia media en el área de Conocimiento del Medio es de 17.4 años. El número de alumnos por profesor es predominantemente de veinticinco alumnos por clase, en el $22.2 \%$ de los casos. 


\subsection{Análisis del Índice de Calidad Didáctica del Material de las maestras participantes en los estudios de casos}

Seguidamente presentamos el análisis de los materiales curriculares de las dos maestras participantes en los estudios de casos a partir del instrumento Índice de Calidad Didáctica del Material (ICDM) caracterizado anteriormente.

En cuanto al análisis de la dimensión 1: Aspectos epistemológicos del material curricular, el material de la maestra 1 obtiene una puntuación de dos, al producirse la identificación del conocimiento escolar con el conocimiento científico. Desde esta perspectiva se asume que el conocimiento cotidiano del niño es esencialmente erróneo. Por el contrario, el material de la maestra 2 obtiene un valor cero, al evidenciarse una comprensión del conocimiento escolar como la resulta de la interacción del conocimiento científico y el cotidiano.

En la dimensión 2: aspectos axiológicos, ambos materiales obtienen una puntuación de uno, al proponer conocimientos culturales y de respeto por el medio.

La tercera dimensión: aspectos psicológicos, incorpora el análisis del tipo de aprendizaje y la función de los conocimientos previos. En el análisis del primer subelemento, tipo de aprendizaje, el material de caso 1 recibe un punto al valorarse que los materiales producen un aprendizaje escasamente relacionado con las ideas e intereses del alumnado. Por su parte, el material del caso 2, obtiene una valoración de cero puntos, desde el momento en que se estima que sus materiales fomentan un aprendizaje significativo que construye conocimiento al relacionar las ideas personales con las nuevas informaciones procedentes de diferentes fuentes de información. Adentrándonos en el análisis de la función de los conocimientos previos, ambos materiales reciben cero puntos al partir de los conocimientos e intereses del alumnado y desarrollarlos a lo largo del proceso de enseñanza y aprendizaje.

La dimensión 4: elementos curriculares, integra el análisis de las competencias clave, objetivos, contenidos, metodología, actividades y evaluación que pasamos a desarrollar.

En el apartado de competencias clave, el material del caso 1 recibe dos puntos, al trabajarse muy pocas competencias clave adecuadamente. Por el contrario, el material del caso 2 recibe un punto al implementarse convenientemente algunas de las competencias.

Con respecto a los objetivos, los dos materiales son valorados con cero puntos ya que estos se caracterizan por orientar los procesos de construcción de los conceptos, modelos, procedimientos y actitudes prioritarias. 
En referencia a los contenidos, se establecen tres subcategorías: a) concepción, b) organización y c) relación con el medio. En referencia al primer elemento: concepción, el material del caso 1 recibe un punto al valorar los objetivos como informaciones procedentes del libro de texto y otras fuentes bibliográficas y telemáticas que deben ser aprendidas por el alumnado. En cambio, el material del caso 2 , recibe cero puntos al concebirse como el conjunto de todas las informaciones procedentes de distintas fuentes y personas que intervienen como materia prima en la construcción y desarrollo de los conocimientos escolares. En el segundo elemento: organización, se repite la misma puntuación que en el apartado anterior, obteniendo el material 1 un punto al abordar los contenidos desde propuestas de globalización forzada (supuesta adición de materias) dentro de una secuenciación lineal. En contraste, el material del caso 2 recibe cero puntos al adoptar un currículum integrado y en espiral. Finalmente, en el tercer subelemento, relación con el medio, ambos materiales reciben cero puntos al presentar los contenidos en interacción directa del alumnado con su entorno social y natural, en el curso de experiencias y vivencias personales (escolares y extraescolares).

Analizando la metodología, el material del caso 1 recibe un punto al situarse en el marco de una metodología de carácter espontaneísta, mientras que el material del caso 2 recibe cero puntos a partir de una metodología basada en la investigación.

El estudio de las actividades integra a su vez tres subelementos: a) concepción, b) tipología y c) secuencia. El primero, concepción, vuelve a reflejar una diferencia entre los dos materiales. Si bien el material del caso 1 recibe un punto al proponer tareas más prácticas que protagonizan los alumnos y que complementan la dinámica expositiva "normal", el material del caso 2 obtiene cero puntos al caracterizarlas como un conjunto organizado de tareas de los alumnos y del profesor que posee una finalidad educativa y que requiere de diferentes materiales y fuentes de información. Por lo que se refiere a la tipología, nos situamos en el mismo escenario, recibiendo el caso 1 un punto al formularse actividades teóricas de índole descriptiva y justificativa que pueden utilizar el libro de texto u otras fuentes (bibliográficas y telemáticas). Por su parte, el material del caso 2, recibe cero puntos al diseñarse actividades teórico-prácticas basadas en tareas de descripción, justificación y argumentación que requieren diversos materiales y fuentes de información. Finalmente, analizando la secuencia de actividades, el caso 1 recibe dos puntos al describir un listado de actividades sin orden ni estructura que responde a los contenidos del material curricular. Mientras, el caso 2 obtiene cero puntos al presentar una secuencia que incorpora adecuadamente distintos tipos de actividades iniciales, de desarrollo y estructuración y de síntesis. 
El análisis del último elemento de la dimensión 4, evaluación, revela la coincidencia de cero puntos para los dos casos, al concebirse como el proceso de comprensión y reflexión para la mejora de la enseñanza y el aprendizaje. Se evalúa al alumnado, al profesorado y los materiales mediante el uso de diversos instrumentos (diarios, análisis de cuadernos, pruebas, entrevistas).

La dimensión 5: diseño de la enseñanza, escenifica de nuevo las diferencias advertidas con anterioridad en los dos casos. De este modo, el material 1 recibe 1 punto al partir del libro de texto y complementarlo con otras propuestas, frente al caso 2 que recibe cero puntos al evidenciarse que el diseño de los materiales es de elaboración propia dentro de la labor docente apoyado por recursos y materiales diversos.

Por último, el análisis de la dimensión 6: desarrollo profesional, revela como el caso 1 obtiene un punto ya que el material mantiene las rutinas escolares, identificándose la implicación docente que potenciaría el desarrollo profesional. Por su parte, el caso 2, recibe cero puntos al evidenciarse que el material promueve el diseño, desarrollo y evaluación del currículum basándose en procesos de investigación escolar.

A partir del análisis de las seis dimensiones y la suma de las puntuaciones de cada material se constata que, el valor del Índice de Calidad Didáctica del Material para el caso 1 es de 1.05. Estamos ante un material curricular de escaso valor didáctico centrado en el libro de texto que la maestra actualiza, para superar las ausencias y los errores que observa. Por el contrario, en el caso 2 el Índice de Calidad Didáctica del Material tiene un valor de 0.19, cercano a la respuesta experta con valor 0. Por tanto, nos encontramos ante un material curricular de alto valor didáctico, que la maestra ha diseñado a partir de un proyecto de trabajo basado en la investigación escolar.

\subsection{Análisis de las categorías del estudio}

Seguidamente comenzamos con el análisis de las categorías de la investigación.

\subsubsection{Materiales para la enseñanza: libro de texto versus material elaboración propia}

Analizando en primer lugar los materiales utilizados en clase, se constata que la mayoría del profesorado (95.1\%) utiliza el libro de texto, frente el 4.9\% que manifiesta no emplear ningún manual. Las 
editoriales más manejadas por el profesorado son Anaya 29\%, Santillana 20.7\%, SM 10.7\%, Edelvives $5.1 \%$, Everest 3.4\% y Vicens Vives 3\% y otras minoritarias.

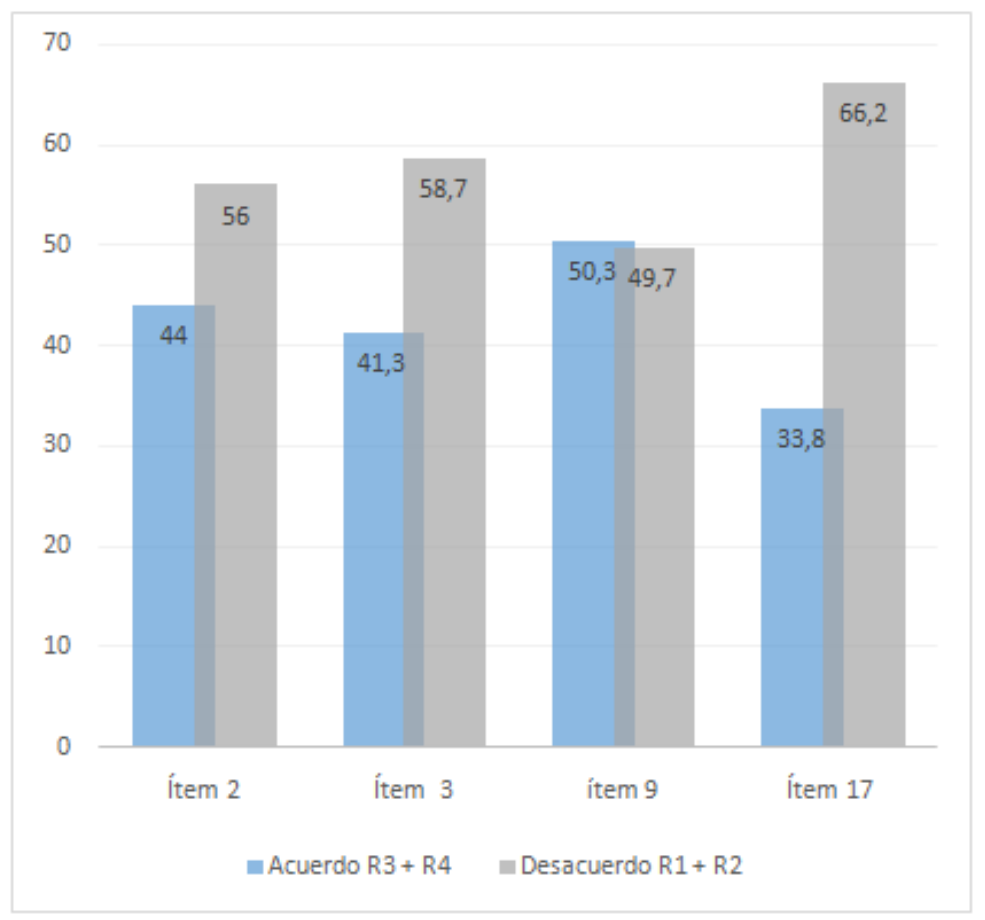

Figura 1. Resultados ítems acerca del libro de texto

Adentrándonos en las valoraciones que hace el profesorado acerca del libro de texto -y que se reflejan de forma conjunta en la Figura 1- es llamativo que, a pesar de su uso mayoritario, las opiniones son a su vez críticas en torno a sus potenciales beneficios para el alumnado. Así, el 56\% del profesorado rechaza que las actividades que propone el libro de texto fomentan el estudio de aspectos específicos del entorno socio-natural del niño (ítem 2), cuestión no menor tratándose del área de conocimiento del medio social y natural. Más sorprendente es el dato referido a la capacidad de los libros para facilitar la participación activa del alumnado en el conocimiento, comprensión y desenvolvimiento en el medio, aspecto ante el que el 66.2\% del profesorado se muestra en desacuerdo (ítem 17). Tampoco se valora de manera positiva la utilidad potencial de los libros de texto para facilitar la comprensión y el logro de aprendizajes significativos, cuestión que rechazan seis de cada diez docentes (ítem 3). A la luz de estos datos es inevitable cuestionar la pertinencia de seguir fomentando la presencia mayoritaria de libros de texto en las aulas -como así se sigue haciendo en la Comunidad Autónoma andaluza a través de una campaña anual de gratuidad- toda vez que el profesorado en su mayoría cuestiona su validez como 
recurso para abordar aspectos esenciales del currículum. Para tratar de conocer la razones por las cuales el profesorado opta por el uso del libro de texto, además de que constituye un material obtenido a partir de las políticas de gratuidad institucionales que el 50\% del profesorado apoya (item 9), exploramos sus percepciones acerca de su utilidad (ítem 46). Los datos reflejan que mayoritariamente el colectivo docente considera que su uso ahorra tiempo (73\%), facilita el trabajo al proponer secuencias de actividades (79\%), permite la selección de los contenidos (62.5\%), facilita el seguimiento de los padres(76.4\%), aporta seguridad y confianza (77.1\%).

Abundando en las ventajas del texto editorial realizadas de forma manuscrita en la casilla de "aclaraciones $y$ dudas" del cuestionario, se alude a la "comodidad" (cuestionarios $\mathrm{n}^{\circ} 68,564,711$ ), el "ahorro de trabajo" (cuestionario 134), su papel como guía de los contenidos (cuestionarios $n^{\circ} 167,296,620$ ), y su capacidad para reducir la incertidumbre al evitar "la improvisación" (cuestionario $\mathrm{n}^{\circ}$ 336). Estas valoraciones muestran que el libro de texto representa un material valorado en tanto y en cuanto simplifica las tareas de diseño y desarrollo del currículum.

En lo relativo a los materiales de elaboración propia del profesorado, se registra que aproximadamente una quinta parte $(22.2 \%)$ afirma diseñar unidades didácticas y materiales complementarios, mientras que solo el 5.4\% trabaja con unidades didácticas publicadas por la Consejería de Educación, constatando el cambio de tendencia que se ha operado en las últimas décadas por los docentes y colectivos innovadores en detrimento de la utilización de materiales elaborados por el profesorado (Pérez Gómez \& Gimeno, 1994).

El análisis de los ítems referidos al uso de materiales curriculares de elaboración propia refleja un panorama sustancialmente diferente al realizado en torno a los libros de texto (Figura 2). Así, el 75.2\% del profesorado considera que las unidades didácticas de elaboración propia elaboradas por los maestros-as parten del estudio del medio donde se ubica la escuela (ítem 7). Además, más de nueve de cada diez docentes refrenda que el uso de unidades didácticas basadas en la indagación de los alumnosas favorece la construcción de aprendizajes significativos en el alumnado (ítem 8). Un dato similar (90.5\% de acuerdo) se registra en la consideración de la necesidad de que el profesorado disponga de materiales curriculares (UD) elaborados y experimentados en la práctica.

Por su parte, en el cuestionario también se preguntaba acerca de las ventajas de la elaboración de los materiales de elaboración propia (ítem 50). Aun siendo una opción minoritaria entre el profesorado, como ya hemos evidenciado con anterioridad, se destacan las siguientes ventajas de su uso que presentamos con datos agrupados: facilita la realización de proyectos de trabajo $(87.9 \%$, ítem $50 \mathrm{a})$ y la 
contextualización de la enseñanza (88.3\%, ítem 50b), permite partir y desarrollar las ideas e intereses del alumnado (89.1\%, ítem 50c) así como incentivar su motivación (85.8\%, ítem 50d).

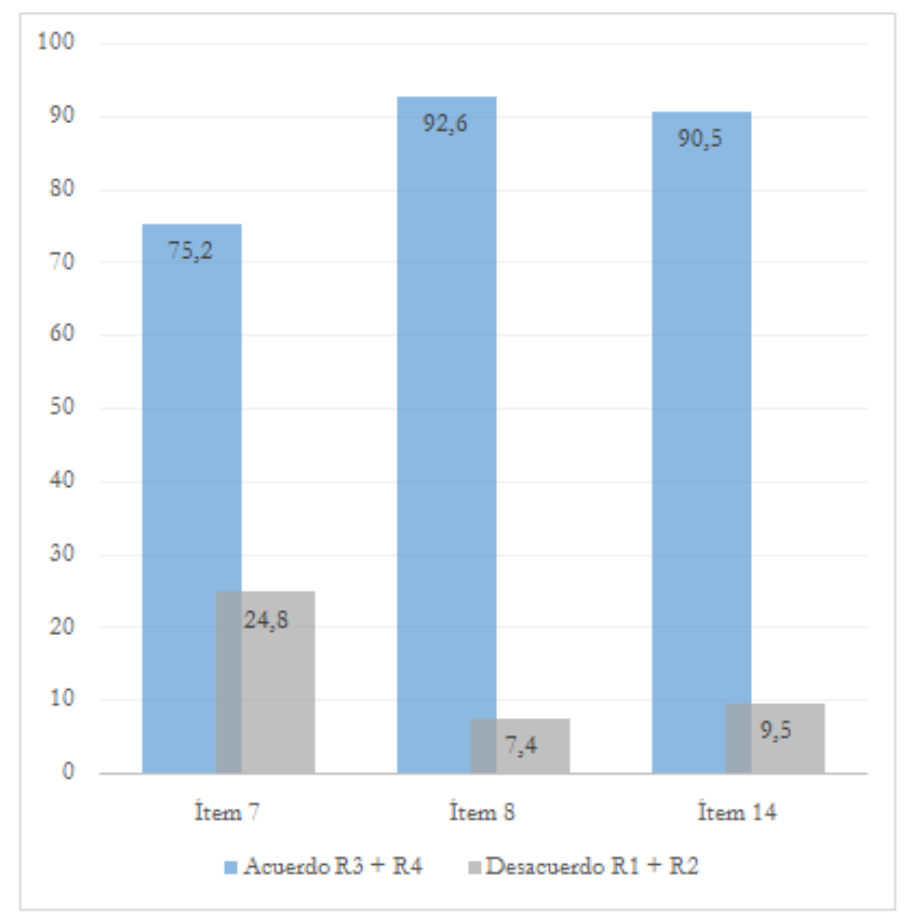

Figura 2. Resultados ítems acerca de materiales de elaboración propia

El profesorado al que se le administró el cuestionario también complementó sus respuestas al ítem 50 con información de carácter cualitativo. Se evidencia que, si bien en líneas generales,los materiales de elaboración propia son percibidos como alternativas más recomendables a la hora de fomentar aprendizajes contextualizados y significativos, también se identifican limitaciones como la falta de tiempo (cuestionario $n^{\circ} 375$ ), la necesidad de contar con equipos para su elaboración (cuestionario $n^{\circ}$ 449) y el aumento de la incertidumbre curricular (cuestionario $n^{\circ} 779$ ).

Como hemos podido observar en los datos del cuestionario existen dos grandes perfiles en torno al uso de los materiales curriculares. Sin embargo, desconocemos en gran medida cuáles son las representaciones y prácticas profesionales que sostienen ambas tipologías docentes en la utilización de los materiales curriculares. Los resultados del estudio de casos van a permitir un mayor acercamiento a la perspectiva de aula. 
Así las maestras que participan en los estudios de casos diseñan y desarrollan materiales de distinta procedencia para enseñar en sus clases. La maestra del primer caso utiliza el libro de texto de la editorial Edelvives, mientras la maestra del caso segundo diseña materiales de elaboración propia empleando recursos múltiples. Ambas maestras poseen en común confianza y autoestima en el trabajo docente, aspectos básicos de la identidad profesional (Zembylas, 2004).

Como decimos, la primera profesora utiliza habitualmente el libro de texto, como la mayoría del profesorado español. La selección de estos materiales, sostiene la profesora, es competencia del equipo docente. "En la etapa de Educación Infantil de este colegio, utilizamos los materiales de la editorial Edelvives, porque el equipo docente considera que se adaptan mejor al entorno y a los niños que tenemos" (63:16, 2804:2804. Entrevista maestra 1).

En esta ocasión se desarrolla la unidad didáctica 8 "El cuentacuentos" del libro de texto de tres años, que tiene como eje motivador el tema de las profesiones, a partir del cual la docente persigue que "los niños/as conozcan el nombre de distintas profesiones y profundicen, vivenciando los conocimientos mediante juegos de simulación y visitas" (63:1, 2500:2500. Memorándum maestra 1, pp. 74).

La profesora utiliza materiales y recursos variados. Las estanterías de la clase están repletas, entre otros, de objetos y juguetes. Las paredes del aula se decoran con el trabajo del alumnado, donde se exponen gorros y guantes de cocineros confeccionados en papel, así como murales con fichas y dibujos. La maestra, no obstante, ha incorporado nuevos recursos, además de los que aparecen en el libro: “la editorial propone el cuento titulado El cuentacuentos, pero era poco motivador y no tenía relación con las profesiones cercanas a los niños. He decidido incluir el cuento de El dragón pastelero, que he adaptado para esta ocasión" (63:2, 2523:2523. Memorándum maestra 1, pp. 75).

Las actividades programadas se basan en el cuaderno de fichas que propone el libro de texto. También la profesora diseña otras tareas que persiguen el interés del alumnado por descubrir el entorno cercano. Así, las excursiones y salidas para conocer las ocupaciones de los bomberos y jardineros, el taller de cocina y de huerto escolar para manipular con objetos y juguetes, o el juego de simulación de roles profesionales, constituyen algunas actividades motivadoras para el alumnado. "Espero que al terminar sean capaces de responder a preguntas como: nombra algunas profesiones, ¿qué hacen?, ¿qué herramientas y vehiculos usan?, ¿qué ropas llevan y porqué?, ¿qué te gustaría ser de mayor?" (63:3, 2501:2506. Memorándum maestra 1).

Por otro lado, la docente participante en el estudio de caso 2 se inclina por los materiales plurales y de elaboración propia frente al uso de un libro de texto como guía. Entre otros motivos expone que "sería muy difícil trabajar un proyecto de investigación escolar a partir de un recurso único" (65:30, 432:432. Entrevista 
maestra 2). En este sentido, considera que las editoriales promueven un recurso cerrado, de escasa conexión con el alumnado y el contexto, a la vez que plantean actividades y contenidos rutinarios y de poca incidencia formativa. En definitiva, "limitan mucho, porque los proyectos que vienen en las editoriales, no conectan con sus intereses (se refiere al alumnado). Traen fichas simples que no tienen complejidad alguna" (65:33, 653:653. Entrevista maestra 2).

La temática elegida para el proyecto ha sido "la alimentación bumana". Este tema se enseña desde una perspectiva funcional y directamente conectada con la promoción de la salud y el desarrollo de hábitos de vida saludables. El estudio de la alimentación "se presenta de forma atractiva, a través de actividades múltiples y prácticas y, además, que sean sugerentes y motivadoras (salidas al entorno, experiencias, observaciones, prácticas, creaciones, etc.)" (65:1, 539:539. Memorándum maestra 2).

La profesora busca y confecciona recursos y materiales en formatos muy diversos: impresos o en soportes físicos, digitales y contextuales. Según manifiesta la maestra "es necesario que trabajen con materiales muy diferentes, existen muchos medios y no podemos reducirlo a uno solo" (65:26, 378:378. Diario del investigador).

Esta tarea resulta en ocasiones excesiva " me veo algo desbordada con los libros viajeros(leer, revisar, repartir, etc.) y es que son muchas cosas a la vez que reclaman mi atención: recursos que aportan desde casa, respuestas a preguntas que han trabajado con sus padres, etc. Y todo ello con el tiempo que tenemos". (65:2, 369:369. Diario maestra 2). A nadie se le escapa la intensificación laboral que implica la confección de recursos por parte de los docentes; para reducir este efecto se ha recurrido al trabajo en equipo y a la implicación de los padres y madres en esta tarea. La participación colectiva ayuda bastante en esta labor "la implicación familiar en todo el proceso es un recurso de inestimable valor y, en este caso, los resultados son muy favorables" (65:3, 563:563. Memorándum maestra 2).

Además de los recursos para la enseñanza, también se han elaborado materiales que ayudan a comprender y analizar la práctica desarrollada. Así, las grabaciones de vídeo, fotos y diarios cumplen con la intención de recoger evidencias para mejorar la acción docente y sus resultados: "Se han realizado fotos y vídeos de la salida" (65:5, 318:318. Diario maestra 2), "Hemos estado grabando la sesión de clase..." (65:6, 393:393. Diario maestra 2) y "De todo el proceso y con muchas actividades concretas estoy haciendo un álbum fotográfico de la experiencia de este proyecto" (65:7, 383:383. Diario maestra 2).

La intervención de esta docente se caracteriza por la incorporación de materiales diversos y complementarios, de acuerdo con una alternativa pedagógica concreta (aprendizaje por investigación), y a partir de la implicación sustantiva del profesorado y otros agentes colaboradores. Como vemos no se trata solo de consumir recursos, también cuenta la acción creativa para su adaptación y elaboración. Y 
ello encierra también un potencial formativo que ayuda al desarrollo profesional y social de todos los participantes.

Recapitulando, en esta primera categoría hemos visto a partir de los datos emanados del cuestionario que la mayoría del profesorado utiliza el libro de texto a pesar de que identifica sus inconvenientes. Esta característica se aprecia en el estudio de caso 1 donde la maestra utiliza el libro de texto sabiendo que no es el material más óptimo. Por ello, se ve en la obligación de complementarlo a través de actividades y recursos múltiples. Por el contrario, un porcentaje mucho menor de la muestra del cuestionario utiliza materiales curriculares de elaboración propia, sin embargo mayoritariamente se reconocen las ventajas que aportan a los procesos de enseñanza/ aprendizaje, como se observa en el $2^{\circ}$ estudio de casos.

\subsubsection{Papel de los materiales curriculares en los procesos de diseño de la enseñanza}

Se presentan en primer lugar los resultados derivados del análisis del cuestionario, abordando el papel de los materiales en los procesos de diseño de la enseñanza y, específicamente, en relación al resto de elementos curriculares, a saber: competencias clave, contenidos, metodología, actividades y evaluación. Se abordan también los procesos de elaboración de los materiales curriculares.

Comenzando con el análisis de los datos a partir de las concepciones acerca de las competencias clave (Figura 3), existe una opinión mayoritaria entre seis de cada diez docentes (íte m 25a, Tabla 2) quienes reconocen la incapacidad de los libros de texto de Conocimiento del Medio natural social y natural p ara desarrollar las competencias a partir de actividades prácticas y la actuación en el medio (ítem 25). En la misma línea se conceptúan las demás competencias: 61.7\%social y ciudadana social (ítem 25b), 65.6\% cultural y artística (ítem 25c) y 69.3\% aprender a aprender (ítem 25d).

Los demás resultados de los ítems de la categoría se presentan en la Figura 4, desarrollándose seguidamente. La dimensión de contenidos recibe una valoración equilibrada en la muestra, con un $50.7 \%$ de acuerdo en relación a la potencialidad de los libros de texto para desarrollar adecuadamente los conceptos clave del área socionatural (tiempo espacio, seres vivos, ecosistemas, máquinas) (ítem 45).

A nivel metodológico, se vuelve a escenificar una tendencia de opinión mayoritaria $(62 \%)$ que coincide en identificar a los libros de texto como responsables de fomentar una metodología convencional y transmisiva (ítem 5). 


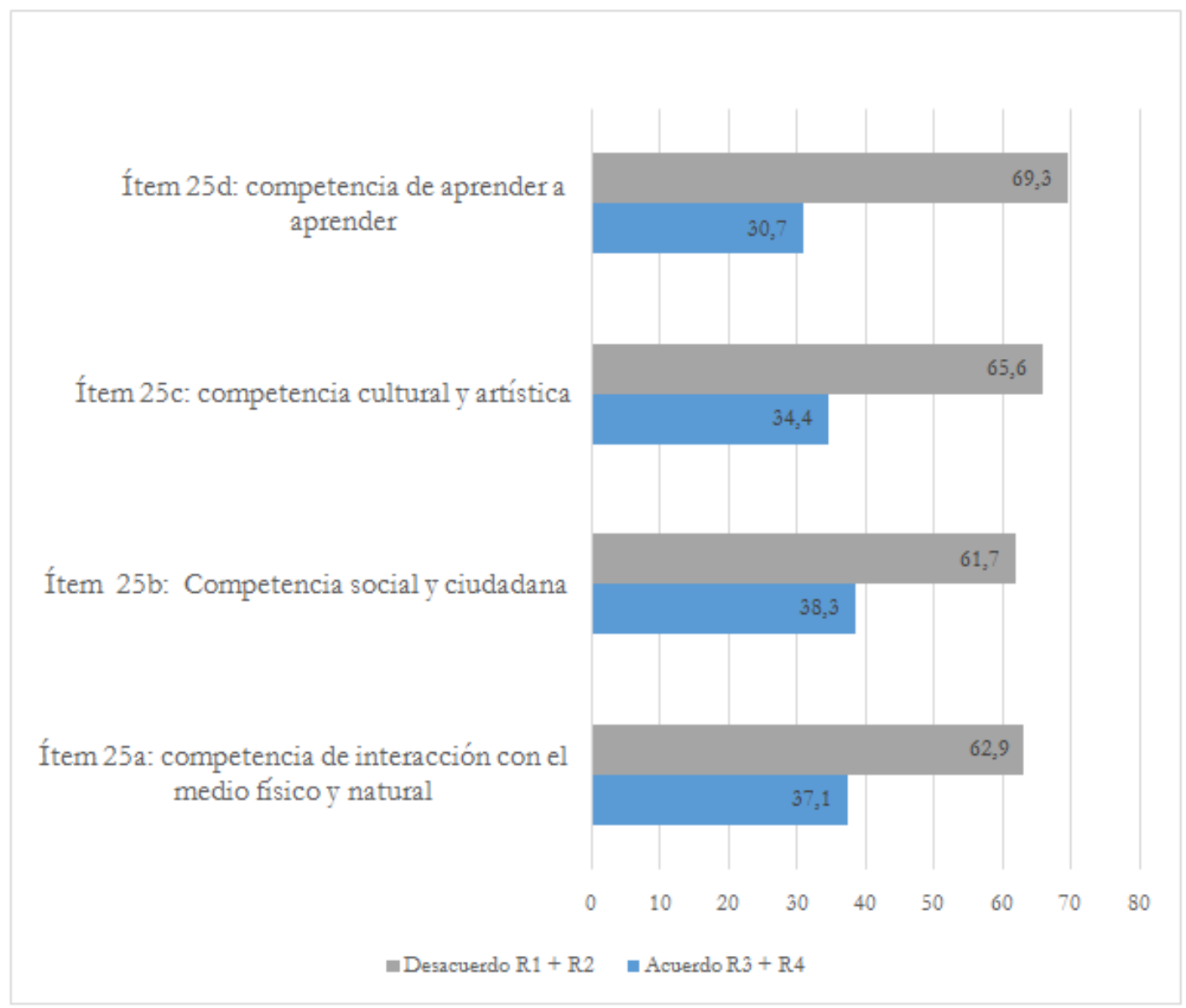

Figura 3. Resultado del ítem 25. Desarrollo de las competencias por parte de los libros de Conocimiento del medio o del entorno

El 51.9\% afirma utilizar materiales curriculares favorecedoras de la indagación y la búsqueda de soluciones a problemas cercanos del alumnado y de la comunidad (ítem 49). Un porcentaje superior $(69.6 \%)$ valora que el uso de unidades didácticas y otros materiales curriculares le permite indagar con sus alumnos-as cuestiones sobre el medio (ítem 30).

Un perfil general de realización de actividades de Conocimiento del Medio evidencia un escenario donde el $73.3 \%$ no realiza salidas al medio (item 31b), el 53.4\% no pone en marcha experiencias ni prácticas (ítem 31c), el 54.8\% no fomenta el trabajo en grupo (ítem 31e); asimismo el 55.6\% afirma no realizar actividades TIC (ítem 31a). Incidiendo en este último elemento vinculado con el uso de tecnologías, siete de cada diez docentes manifiestan la escasez de actividades TIC incluidas en los libros de texto (ítem 18). La actividad mayoritaria entre el profesorado es la realización de debates en sus aulas (65\%, ítem 31d). 


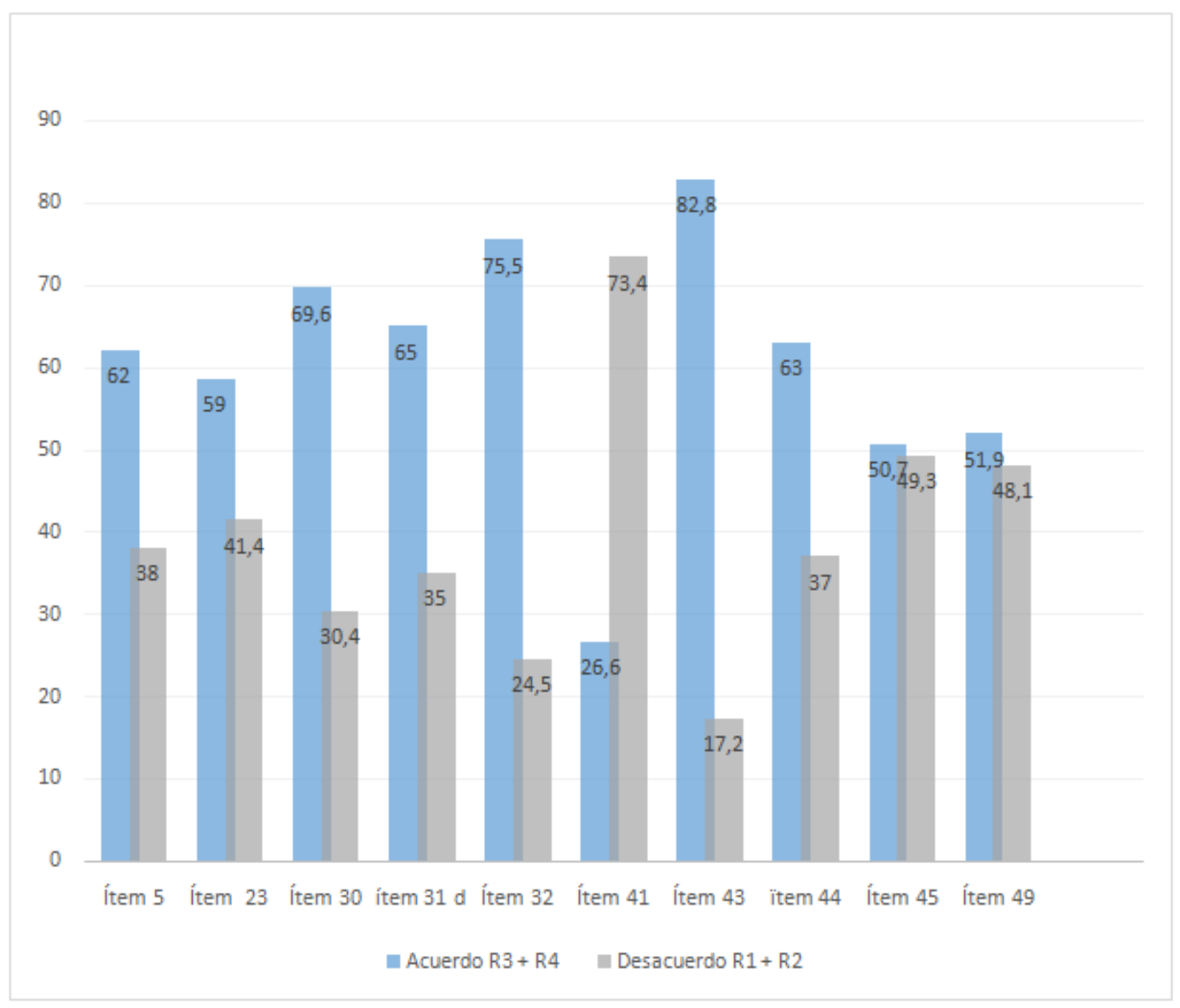

Figura 4. Resultado de los ítems acerca del papel de los recursos en el diseño de la enseñanza

Las implicaciones de uso del libro de texto en el aula se valoran en términos de la necesidad de explicar continuamente para que los alumnos realicen las actividades (63\%, ítem 44). Ocho de cada diez docentes $(82.8 \%)$ valoran la posibilidad de contar con materiales diversos que puedan adaptar a su práctica (ítem 43).

En cuanto a la evaluación, el 58,6\% realiza una prueba oral o escrita de los contenidos tratados en el libro de texto (ítem 23), sin embargo, la calificación no se produce a partir de los exámenes proporcionados por el libro del maestro por parte del 73.4\% (ítem 41). El 75.5\% del profesorado evalúa a sus alumnos-as mediante la participación y los trabajos individuales y grupales realizados en clase (ítem 32).

El subsiguiente análisis de los estudios de casos ilustra prácticas de aula fundamentadas en la necesidad de responder activamente a esas grandes limitaciones que se perciben en los libros de texto cuando se utilizan como recurso único. 
Así, situados en un gradiente representando la mayor o menor dependencia del libro de texto,el caso 1 estaría en el tránsito hacia la independencia del material cerrado, desde el momento en que la programación de la enseñanza que realiza la profesora es coincidente con los distintos elementos curriculares del manual. La maestra selecciona, en gran medida, los objetivos que propone el libro de texto (63:5, 233:233. Programación maestra 1): "Conocer algunas ocupaciones de los hombres y las mujeres de nuestro entorno, identificar algunas profesiones y servicios relacionados con la seguridad y la sanidad, reconocer los instrumentos y uniformes más característicos de cada profesión". Respecto a los contenidos, son los mismos que enuncia el manual escolar a los que la maestra incorpora nuevos conocimientos relacionados con el estudio de otras ocupaciones: las profesiones del agricultor y del jardinero, los trabajos de los hombres y las mujeres: bombero, panadero, cocinero, pastelero, médico, policía y camarero. El respeto a todas las profesiones sin discriminación de género, así como los servicios relacionados con la seguridad y la sanidad (63:6, 255:255).

La secuencia de actividades del manual escolar está articulada en torno a un conjunto de fichas, cuya finalidad principal radica en ejercitar tareas de motricidad fina del alumnado. Las fichas representan una propuesta de trabajo fragmentaria e inconexa con la temática del estudio de las profesiones, que la profesora trata de adaptar a su clase con desigual resultado: "Las fichas que presentaba el libro del alumno eran muy simples y de contenido escaso y descontextualizado. La solución ha sido usar este material ampliando los contenidos propuestos por la editorial" (63:7, 2525:2525. Memorándum maestra 1). También emplea materiales diversos y cotidianos para las actividades iniciales de exploración de ideas previas del alumnado, como la "caja mágica", que sirve a la docente para simular el oficio del prestidigitador, haciendo aparecer y desaparecer objetos, juguetes y personas: "Profesora: jva a salir un bombero...! ¿Qué hace un bombero? (Los alumnos-as simulan que van montados en un camión haciendo el sonido de la sirena). P: ¿y qué más hace un bombero? ¿A dónde vamos con el camión?. Alumno 1: a rescatar a un gato" (63:8, 1303:1308. Transcripción grabación vídeo). Entre las actividades de síntesis destacamos "el libro de las profesiones", consistente en un pequeño libro que ha elaborado cada niño-a a lo largo del tiempo de duración de la unidad, en el que "se encuentran varias profesiones y sus herramientas. Se repasan los dibujos del agricultor y la docente pregunta ¿qué herramientas utiliza?, ¿qué recolectan?” (63:9, 2754:2754. Diario de investigador). Otra actividad consiste en dramatizar la profesión que al niño le atrae. La profesora cuestiona: " $a$ mí me gustaría ser...”. Todos los niños-as describen qué quieren ser" (63:10, 2754:2754. Diario de investigador).

La evaluación realizada por la profesora ha tenido en cuenta las concepciones previas del alumnado y ha sido eminentemente formativa y de carácter cualitativo, realizándose "mediante juegos y diálogos en la asamblea, en los que expresaban sus opiniones y aprendizajes" (63:11, 2517:2517. Memorándum maestra 1). 
La segunda maestra participante se plantea el diseño de su experiencia en función de determinados temas significativos para la formación integral de los escolares. La opción que esta docente adopta para estudiar la alimentación humana se fundamente en un enfoque funcional "que no se quede en un conocimiento para la clase" (65:42, 421:421. Entrevista maestra 2).

El diseño de la enseñanza no sigue la propuesta de ningún proyecto editorial. La profesora consulta distintos documentos para la actualización científica y así se "realiza una primera versión, tras consultar algunos documentos -libros, revistas, información digital, programas de campañas oficiales de la Junta de Andalucia, etc.-" (65:4, 541:541. Memorándum maestra 2). Seguidamente se adapta en función de las ideas y preguntas de los escolares hasta llegar a la programación del proyecto. El proceso de "análisis didáctico" implica la utilización de varios materiales elaborados por la docente como una presentación digital para agilizar la conversación sobre las ideas iniciales o la confección colectiva de una red de preguntas que sistematice y ordene el trabajo escolar a lo largo del proyecto de investigación. Temática, revisión científica, adaptación didáctica y proyecto constituyen un proceso participativo, sólidamente informado.

Y, por esta razón, cuando planifica, la maestra argumenta los motivos de la selección de la temática, tratándose en este caso de "una cuestión socialmente relevante y que conecta con los contenidos esenciales del curriculum; sin olvidar que permite distintas actividades prácticas para abordarlas en la dinámica de clase" (65:44, 328:328. Diario del investigador).

Los objetivos definidos por la maestra "se enuncian con un carácter expresivo y, en este sentido, plantean referencias a considerar para el desarrollo de las experiencias, más que metas cerradas para todo el alumnado" (65:8, 49:49. Programación maestra 2).

El contenido se organiza de forma integrada, de modo que las distintas áreas y conocimientos se presentan, "como un todo relacionado en el que caben distintos contenidos y conocimientos coherentes entre si" (65:9, 84:84. Programación maestra 2).

Los objetivos y contenidos seleccionados hacen referencia a diversos aspectos de la vida, el desarrollo de los valores personales y sociales o los procedimientos diarios asociados a la alimentación: “hemos seguido un esquema integrador que asegure la relación entre los distintos conocimientos y experiencias, lo que facilita la comprensión del aprendizaje escolar y su posible traslado a la vida cotidiana" (65:10, 553:553. Memorándum maestra 2). La higiene, el comensalismo, la responsabilidad, el reparto de tareas, la sensibilidad artística, el mercado, la compra, el presupuesto..., son algunos aspectos recogidos en esta experiencia y que pocas veces aparecen en las típicas lecciones de los manuales más extendidos. 
Las actividades propuestas plantean variadas formas de trabajar el tema del proyecto; entre otras, las siguientes:

- Experiencias prácticas: "a los alumnos del taller de cocina los he visto muy activos y con mucho interés" (65:11, 382:382. Diario maestra 2).

- Interacción con el medio: "actividades que ponen en contacto con la realidad; hemos realizado diferentes salidas por la localidad: frutería, supermercado, panadería, etc., de modo que la experiencia educativa se abra al entorno y permita el flujo entre la vida y el ámbito escolar" (65:12, 552:552. Memorándum maestra 2).

- Manejo de recursos digitales: "otro grupo ba estado trabajando con el ordenador en Internet. Se les está iniciando a manejar estos recursos a partir de actividades del proyecto: el ordenador les encanta y se les ve bastante resueltos" (65:13, 398:398. Diario maestra 2).

- El juego como recurso educativo: "diferentes situaciones de juego que se establecen en el aula y favorecen diversos aprendizajes" (65:14, 556:556. Memorándum maestra 2).

En definitiva, un itinerario de actividades diversas regido por unos criterios explícitos: "Contacto con la realidad. Enfoque colaborativo. Atención a la diversidad. Participación familiar y de otros agentes. La participación activa" (65:15, 550:550. Memorándum maestra 2). Y todo con el propósito de trascender a un conocimiento exclusivamente academicista basado en "respuestas correctas" de poca utilidad más allá del contexto en el que se aprendió.

Como podemos ver, en todo momento se ha tratado de superar la secuencia de fichas: "Nosotras hacemos murales, dramatización, salidas, conversación, experiencias, muchas cosas antes y no se reduce a completar un ejercicio en formato papel' (65:48, 579:579. Entrevista maestra 2).

Esta variedad de experiencias y actividades es posible gracias a la participación de diferentes colaboradores (familias, voluntarios y otros agentes), pues "sin esta participación sería muy difícil desarrollar los proyectos; una persona sola lo tiene muy difícil' (65:50, 587:587. Entrevista maestra 2).

El proceso de evaluación tiene un carácter formativo, con la finalidad de promover unos conocimientos finales sólidos y duraderos. Se han empleado múltiples recursos para esta secuencia evaluadora: tramas en evolución, álbum del proyecto, juego de preguntas, presentaciones digitales, revisión progresiva de las producciones, etc. Con estos medios se recogen evidencias plurales y no solo "respuestas correctas" basadas en una información única y cerrada. "Para evaluar, entre otros recursos empleamos la trama, el álbum en el que vamos recopilando todo lo que es importante y las fotografías porque, a veces, muchas experiencias no las puedes 
recoger por escrito, pero las fotos te ilustran perfectamente cómo se ha desarrollado esa actividad" (65:53, 564:564. Entrevista maestra 2).

La maestra no depende de un medio, ni de un proyecto. Son muchas las decisiones que se toman (contenidos, recursos, actividades, organización, evaluación, etc.) para poder adaptar la secuencia de enseñanza a las características del alumnado y su contexto. Y eso, con un manual único, no es posible pues, como afirma la maestra, las actividades puestas en juego "no son experiencias aburridas, no son monótonas. Los niños aprenden con entusiasmo" (Entrevista maestra 2, pp. 5).

El análisis de los datos de la segunda categoría ha permitido visualizar el diferente papel que juegan los diversos materiales curriculares en los procesos de enseñanza. Tanto los resultados del cuestionario como los de los estudios de casos muestran que el profesorado manifiesta representaciones diferenciadas en torno al libro de texto y los materiales de elaboración propia. De este modo, la selección de una tipología u otra de material implica cambios en el resto de elementos curriculares. Así, mientras los docentes que utilizan los libros de texto se convierten en aplicadores de diseños externos -pudiendo o no complementarlos con otros recursos- aquellos que crean sus propios materiales toman control de los procesos de diseño y desarrollo de la enseñanza.

\subsubsection{Influencia de los materiales curriculares en el modelo didáctico del profesorado}

La última categoría del estudio persigue examinar la relación entre los materiales y el modo de enseñar. A este respecto, el análisis comparativo entre los distintos tipos de materiales refleja diferencias sustantivas a la hora de conceptuar las repercusiones de los libros de texto frente a los materiales de elaboración propia.

Así, mientras que el $75.7 \%$ de los docentes rechaza que el uso del libro de texto fomente una mejora de su formación docente (ítem 28, Figura 5), el 85.7\% identifica a la elaboración de materiales curriculares propios como un factor clave en el aumento de su desarrollo profesional (ítem 39).

En esta misma línea, se valoran muy positivamente no sólo los procesos de diseño de los materiales sino su desarrollo en la práctica por parte del $74.1 \%$ del profesorado (ítem 36).

En consonancia con los datos generales del cuestionario, las implicaciones de seleccionar un material frente a otro en el modo de enseñar son patentes una vez se analizan los procesos que acontecen a nivel de aula a partir del desarrollo de los estudios de casos. Así, en el caso 1, donde el material predominante 
es el libro de texto, las tareas de la profesora y del alumnado están condicionadas por el manual escolar, que dirige en gran medida la actividad de la clase. Es perceptible como las grandes decisiones didácticas que adopta la profesora pertenecen al libro (objetivos, contenidos, actividades...), si bien esta aporta algunos materiales y actividades vivenciales, al comprobar la escasa adecuación del libro de texto a la temática de las profesiones: "personalizo las programaciones del libro de texto, adaptándolas a mi forma de entender el proceso de enseñanza y aprendizaje" (Cuestionario F, ítems 82).

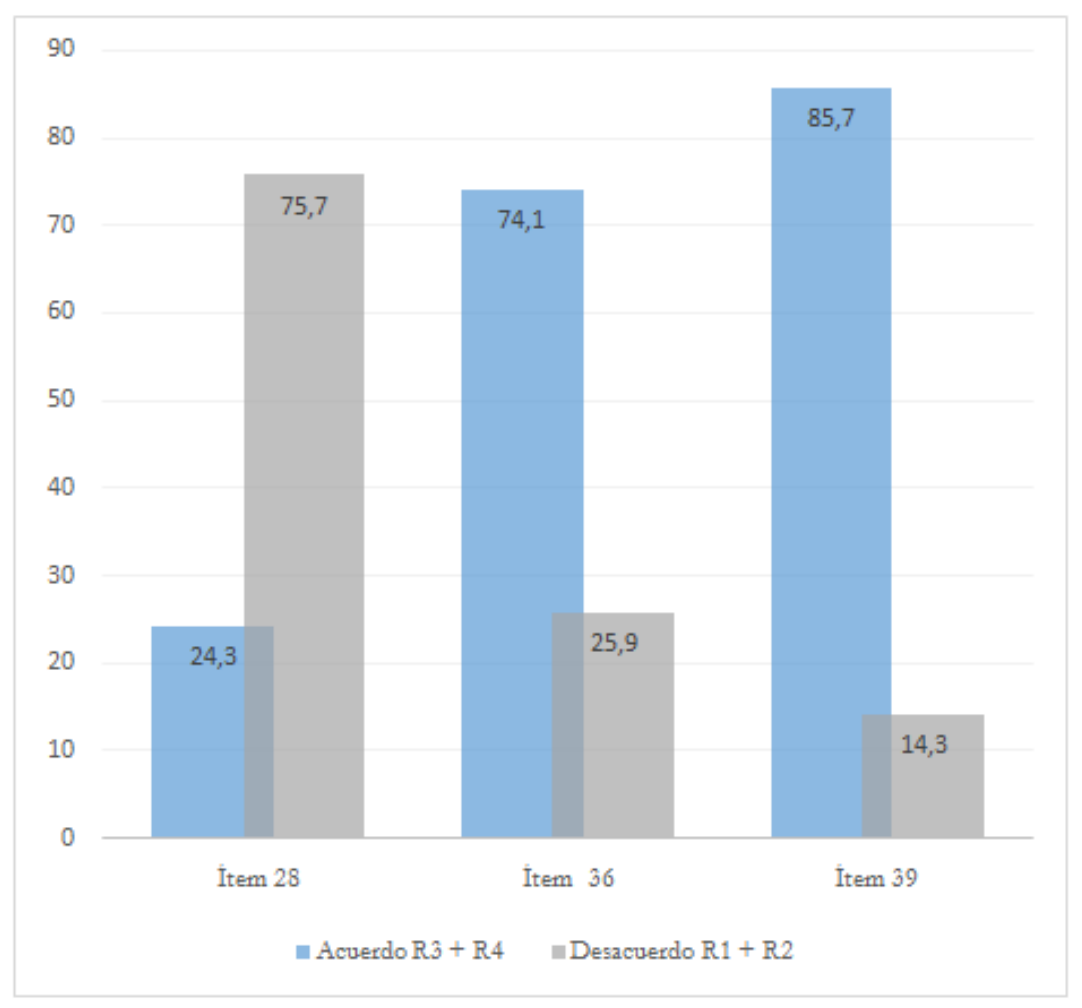

Figura 5. Resultado de los ítems acerca dela influencia de los materiales curriculares en el modelo didáctico del profesorado

La maestra se fundamenta en el principio de actividad al considerar que el alumnado "aprende haciendo". Para ello desarrolla sus habilidades comunicativas y musical es para concitar la actividad infantil, manejando los materiales y recursos con pericia y obteniendo resultados positivos al concentrar la atención y participación del alumnado de tres años. Por ejemplo, la docente obtiene de una estantería un "bolso mágico" y pregunta al alumnado por el nombre de las profesiones: "Profesora. Voy a ver qué sale del bolso mágico... Alumnos. ¡Un gorro! P. ¿Quién lo utiliza? ¿Para qué sirve? (...)” (63:12, 1807:1816. Transcripción vídeo). 
Las actividades de experimentación en el huerto o en las salidas se combinan con otras dedicadas a la simulación de situaciones cotidianas con la finalidad de estimular la curiosidad, empatía, expresión corporal y autoestima del alumnado: "La profesora introduce el tema de las profesiones preguntando: ¿sabéis quiénes se tiran por una barra? Un niño responde: los bomberos. A partir de abi escenifican y dramatizan la profesión" (63:13, 2612:2612. Diario del investigador).

La maestra justifica el diseño y desarrollo de la unidad argumentando que el libro ha sido un recurso más de los que ha utilizado. Es indudable que una utilización flexible del libro de texto ha favorecido la consecución de los objetivos propuestos:

"A la hora de presentar esta unidad, he tenido que usar muchos recursos propios (materiales de apoyo, actividades, juegos...). El libro de la editorial, tanto la guía como el libro de los niños, me han servido como otro recurso más a tener en cuenta, no como algo cerrado que hay que seguir. Yo soy la que decido cómo lo uso, intentando que condicionen mi trabajo lo minimo" (63:14, 2521:2521. Memorándum maestra 1).

La maestra se encuentra en un momento de tránsito entre un modelo de desarrollo profesional convencional y otro de carácter activo e innovador (Cañal et al., 2011), que expresa con entusiasmo: “ $A$ pesar de los obstáculos, estoy muy satisfecha con el trabajo realizado. Creo que los alumnos se lo han pasado muy bien, han aprendido lo que pretendía y algunas cosas más que han ido surgiendo" (63:15, 2530:2530. Diario profesora 1).

Cuando observamos la dinámica de clase de la maestra del estudio de caso 2, comprobamos la relación que se establece entre los materiales y la acción educativa. No sería posible desarrollar una experiencia de investigación escolar a partir del manejo de un recurso único y cerrado del tipo libro de texto o sus sucedáneos (fichas, etc.). Tampoco estos materiales encajan bien con actividades abiertas y creativas. Autonomía y cooperación son dos principios didácticos que la maestra mantiene y los materiales empleados lo fomentan en la medida que "promueven aprendizajes compartidos e interacciones entre iguales (murales, rincón de la tienda, talleres, etc....) a la vez que facilitan la socialización y las relaciones plurales y entre iguales" (65:56, 125:125. Proyecto educativo).

La participación se amplía al ámbito doméstico y comunitario. Así, la implicación de la familia y otros agentes es frecuente; aportar recursos incumbe a todos, pero no sólo por su valor material sino también por el sentido colectivo que le imprime a la actividad educativa "porque para poder aprender con sentido, es necesario que participemos todos. Solo asi los contenidos alcanzarán su verdadero significado" (65: 54, 527:527. Entrevista maestra 2). 
Los materiales fomentan no solo el consumo de datos y la recopilación de información, sino la producción de conocimiento: “queremos que además de consultar sean capaces de hacer, crear y presentar resultados y respuestas a las preguntas" (65:60, 493:493. Entrevista maestra 2).

En definitiva: se oyen otras voces (visitas de los expertos), se conocen otros escenarios (visitas al medio: tienda y mercado), se experimenta para comprobar y sacar conclusiones (taller de los experimentos y taller de cocina), se accede a información (libros de consulta) o se manejan distintos formatos digitales (ordenador, cámara digital y presentaciones digitales, etc.).

La confección de materiales reporta un doble significado con respecto al libro de texto. Por un lado, se trabaja con recursos adaptados a la actividad y a unos escolares concretos; y, por otro, permite reflexionar sobre la enseñanza y el contenido que se quiere trabajar con el componente formativo que esa labor encierra. Sostiene la profesora: "los libros de texto no están a la altura de nuestros proyectos" (65:66, 474:474. Entrevista maestra 2).

La maestra tras varios años de implicación en proyectos de innovación e investigación muestra un desarrollo profesional sólido y coherente. En la actualidad es capaz de preparar, buscar, adaptar y crear recursos y materiales que le ayuden en sus iniciativas sin dependencia o pérdida de protagonismo pedagógico.

El análisis de ambos casos ha permitido evidenciar que las concepciones y prácticas sobre la elaboración y uso de materiales curriculares de las docentes presentan similitudes y diferencias. En cuanto a las similitudes, se observa un enfoque didáctico de carácter innovador que prima la utilización del entorno, los materiales variados, las actividades vivenciales, los talleres, el juego, así como la colaboración familia-escuela. Respecto a las diferencias, radican en el nivel de desarrollo profesional alcanzado por ambas profesoras. Así en el caso 1, se constata una menor autonomía pedagógica y gran dependencia de las decisiones del texto, que son asumidas, por lo general, en la práctica docente. Mientras, en el caso 2, la elaboración de materiales contextualizados por la profesora genera mayor independencia curricular. El incremento de la autonomía docente estimula aún más el desarrollo profesional basado en propuestas de investigación escolar y viceversa.

Para concluir con el análisis de la tercera categoría podemos afirmar que la selección de una tipología u otra de material curricular repercute en la forma por la cual el profesorado desarrolla su actividad docente, revelándose los procesos de elaboración de materiales como positivos para el fomento de la profesionalidad docente y su modo de enseñar. Estos resultados señalan la necesidad de arbitrar fórmulas para apoyar los procesos de elaboración de materiales en el colectivo docente, desde la 
necesidad de trascender al papel de meros aplicadores de diseños externos para convertirse en expertos en los procesos de diseño y desarrollo del currículum.

\section{Conclusiones y discusión}

Los dos estudios realizados-extensivo e intensivo- han permitido indagar en las concepciones y prácticas de los docentes sobre el diseño y desarrollo de los materiales de enseñanza tanto a nivel extensivo -a través del cuestionario- como intensivo, a partir del desarrollo de los dos estudios de casos. Los resultados obtenidos permiten formular las conclusiones que se presentan en función de las preguntas de investigación:

Responder a la primera pregunta de investigación relativa a la categoría: ¿Qué materiales se emplean en clase? permite validar una creencia generalizada en torno al papel aún predominante del libro de texto en el sistema educativo, como así han demostrado otros estudios (Issitt, 2004; Varela, 2008; Bayona, 2009), no obstante se observa una amplia diversidad en su uso y resultados (Sosniak \& Stodolsky, 1993), por tanto, se precisan estudios en los escenarios prácticos que ayuden a comprender y mejorar sus posibilidades (Moulton, 1997). Incluso en el análisis de prácticas docentes comprometidas con la investigación educativa, como la evidenciada en el caso 1, se identifican modelos curriculares de adherencia al texto comercial. Sin embargo, también se constatan prácticas de elaboración de materiales curriculares, que aun minoritarias, permiten concluir que un sector del profesorado apuesta por invertir en procesos de elaboración e implementación de sus propios materiales. Una buena prueba de ello la encontramos en el análisis del caso 2, en el que la docente se halla comprometida con el desarrollo de sus materiales curriculares, tomando distancia de los textos y materiales comerciales y obteniendo además una diferencia de 0.86 puntos con la maestra del caso 1 a partir del análisis del Índice de Calidad Didáctica del Material (ICDM). En esencia, el análisis comparativo de los casos evidencia que la adopción de materiales alternativos supone seguir un camino progresivo y complejo que avanza a través de experiencias, consolidando posiciones cada vez más elaboradas respecto a la enseñanza (Maestro, 2002; Pinto, 2007; Grossman \& Thompson, 2008; Reininger, 2010). En coincidencia con los estudios anteriores, observamos como las primeras tentativas más sencillas son los pasos iniciales para alcanzar posiciones más sólidas y fundamentadas.

Para analizar la segunda pregunta de investigación de la categoría 1: ¿Por qué se seleccionan los materiales curriculares?, es preciso llamar la atención sobre los múltiples factores-tanto internos como externos- que inciden en los procesos de decisión en torno a la adopción de los materiales. Por ejemplo, 
la presencia de la política de gratuidad en la Comunidad Autónoma hace que por definición los libros de texto estén presentes en los centros educativos, cuestión distinta es que el profesorado decida hacer uso de los mismos. Dilucidar una respuesta unívoca a esta pregunta supone hacer el cruce entre las concepciones y prácticas del profesorado, los contextos en los que desarrollan su actividad, sus niveles de desarrollo profesional y su trayectoria. Así, aunque los datos evidencian que tanto los libros de texto como los materiales de elaboración propia son muy bien valorados, son los primeros los mayoritariamente utilizados en las aulas.

Abordando las cualidades que hacen del libro de texto un recurso de uso extendido, se identifican -entre otros- dos elementos clave que podrían estar detrás de su elegibilidad:la variable tiempo y la reducción de la incertidumbre. La dimensión temporal es una invariable común a la práctica docente (Adelman, Panton, Eagle \& Hargreaves, 2003; Hargreaves, 1996), representando un factor al que con frecuencia se alude para justificar lo que se percibe como posible en el contexto de la práctica educativa. En este sentido, no es aventurado considerar que la percepción del libro como elemento que ahorra tiempo influya en la decisión en torno a su uso, si bien serían precisos estudios que indaguen exactamente sobre el grado en que el ahorro de tiempo determina la selección del material. Asimismo, la reducción de la incertidumbre es otro factor clave en el ejercicio de la actividad docente, que precisamente el libro de texto contribuye a reforzar aportando seguridad y confianza, proponiendo secuencia de actividades, la selección inmediata de los contenidos así como facilitar el seguimiento por parte de las familias. En este sentido, los libros de texto se convierten en recursos que centralizan la toma de decisiones curriculares, estando ideados para seguir la secuencia que aparece en sus páginas (Soto, 2006; Campagno, Castillo \& Ferrero, 2009). Cuando la fidelidad se rompe es fácil que surjan tensiones o rechazo entre los distintos usuarios (alumnado y padres) y equipo docente, acostumbrados al manejo automático de estos manuales. Ese conflicto puede frenar e incluso acabar con iniciativas incipientes destinadas a complementar el manual con otros recursos o según una lógica distinta a la recogida en el texto.

Sin embargo, se evidencia que las múltiples ventajas del libro de texto identificadas por el profesorado se circunscriben fundamentalmente al desarrollo y condiciones de la acción docente. De este modo, cuando se analizan los potenciales beneficios para el aprendizaje y desarrollo de las competencias clave se escenifica un panorama menos alentador, en el que se reconoce que el libro comercial es un material descontextualizado de los entornos en los que se utiliza, que inhibiría la participación activa del alumnado en el medio o la adquisición de aprendizajes significativos. Estas evidencias son suficientes para llamar la atención sobre la necesidad de futuras investigaciones que contribuyan a comprender las 
razones del uso mayoritario de un material del que a su vez se destacan importantes deficiencias para promover el aprendizaje, finalidad de todo acto educativo. En la misma línea, sería interesante indagar porqué los materiales curriculares de elaboración propia -pese a recibir muy buenas valoraciones por parte del profesorado que destaca su contextualización con los entornos cercanos, su potencialidad para fomentar la indagación y el aprendizaje significativo- siguen siendo de uso minoritario entre el profesorado. Concluimos, por tanto, que el análisis comparativo de las valoraciones en torno a las ventajas del uso de los diferentes materiales refleja que mientras que el libro de texto es percibido como un un facilitador de los procesos de enseñanza -por tanto se enjuician sus ventajas desde la óptica docente-, los materiales de elaboración propia se identificarían como coadyuvantes en los procesos de aprendizaje, existiendo un consenso mayoritario en cuanto a sus bondades para contribuir al aprendizaje significativo entre el alumnado. Se aprecia, por tanto, una clara paradoja según la cual a grandes rasgos el profesorado utiliza el libro de texto a pesar de valorar la mayor idoneidad del material de elaboración propia.

La mirada intensiva desarrollada a partir de los estudios de casos permite comprender porqué se seleccionan unos materiales frente a otros. Así, se constata cómo el modelo didáctico de las docentes condiciona notablemente el diseño y la práctica de los materiales curriculares en el aula. De este modo, la profesora del caso 1 se encuentra en un momento de cambio de un modelo didáctico convencional a otro de carácter innovador. Este tránsito profesional está fundamentado en la actividad de niño-a, siguiendo el principio de "aprender haciendo". La reelaboración del manual representa una primera tentativa para el cambio de modelo. La profesora del caso 2 posee, por el contrario, una dilatada experiencia educativa en proyectos de trabajo, fruto de un desarrollo profesional investigativo. Su práctica educativa se basa en la independencia y la cooperación. Estos principios aseguran su autonomía pedagógica para elaborar su propio material escolar, adaptado al contexto y a las concepciones e intereses del alumnado. Podemos concluir, por tanto, que la utilización de materiales curriculares depende en gran medida del modelo didáctico del profesor que determina el nivel de desarrollo profesional. Los docentes modifican sus concepciones y prácticas de aula en la medida que usan o elaboran materiales curriculares a lo largo del tiempo. Este hallazgo ha sugerido a diversos autores la presentación de una trayectoria o progresión deseable para el uso de materiales (Grossman \& Thompson, 2008; Kasim, 2008; Cañal et al., 2011).

Con la finalidad de facilitar los procesos de elaboración propia de materiales y el desarrollo curricular por parte de los docentes existen algunos proyectos editoriales, como el Proyecto Investigando Nuestro Mundo (INM 6-12) (Cañal, Pozuelos \& Travé, 2005) que facilitan la intervención decidida de los 
docentes según su propia propuesta didáctica, compensando de alguna manera el abismo percibido entre aquellos que deciden trascender a las ofertas comerciales. La propuesta curricular ofrece materiales, recursos, orientaciones y ejemplos que pueden ser distribuidos de forma personal. Este modelo está poco extendido y menos estudiado (Reininger, 2010), aunque encierra un potencial que a nadie escapa. Y algo en lo que coincidimos: cuanta más independencia se tiene respecto a los manuales herméticos más se gana en profesionalidad y mejora la credibilidad del docente (Stenhouse, 1987; López Hernández, 2007).

La primera pregunta de investigación de la segunda categoría: ¿Qué papel desempeñan los materiales en relación a los elementos curriculares? permite indagar en las interacciones entre materiales y elementos del currículum. De este modo, se caracterizan las interacciones entre el uso de los materiales y los diferentes elementos curriculares. Por ejemplo, se evidencia una mayoritaria percepción de la escasa potencialidad de los libros de texto para fomentar las competencias claves, la división entre el profesorado acerca de la capacidad de los libros para desarrollar los contenidos, el consenso mayoritario para enjuiciar a los libros de texto como responsables de fomentar metodologías transmisivas o la necesidad de explicar continuamente para que el alumnado realice las actividades. Porcentajes similares señalan, por contra, las bondades de los materiales de elaboración propia para indagar acerca de cuestiones del medio cercano. Se pone de relieve que una mayoría del profesorado realiza pruebas orales y escritas de los contenidos abordados en el libro de texto, evidenciándose por tanto que la utilización de un material determinado ejerce una clara influencia sobre el ejercicio de la actividad evaluativa, si bien esta se complementa con diferentes instrumentos como la realización de trabajos.

Por otra parte, los posicionamientos de uso flexible del libro de texto apuntarían a que la percepción del manual como simple recurso de apoyo, representa una visión escasamente elaborada, como así se demuestra en el análisis riguroso a partir de evidencias realizado tras el desarrollo de los estudios de casos. De este modo, se pone de relieve que las grandes decisiones curriculares se toman a partir de los dictámenes del libro de texto, relegando la actividad de la docente a una mera complementación a partir de recursos extra o actividades derivadas de las ya propuestas en el material. Este panorama se ve completamente revertido en la docente del caso 2, quien ejerce un total control de las decisiones curriculares, desarrollando su actividad a partir de una secuencia didáctica de investigación escolar y la elaboración de sus propios materiales.

En referencia a la segunda pregunta de investigación de la segunda categoría "¿Cómo se elaboran los materiales curriculares?" concluimos que se detectan dos enfoques diferenciados en virtud de su dependencia o independencia del texto comercial. Así, el primero se basa en la reelaboración del 
manual escolar que en ciertos casos -como el descrito en el estudio de caso 1, se emplea con cierta creatividad y flexibilidad. Esta práctica cuestiona una apreciación, tan extendida como inexacta: “el uso del libro de texto genera siempre prácticas rutinarias y aprendizajes de memoria". Y, otro, fundamentado en el diseño de proyectos de trabajo por investigación escolar, vertebrado en torno a una fundamentación teórica de la práctica. La incorporación de diversos materiales contextualizados en el entorno y en los intereses del alumnado permite,como se observa en el caso 2, la consecución de un currículum integrado y un aprendizaje funcional. Esta práctica también cuestiona otra generalización muy amplia e igualmente errónea: "la elaboración de materiales propios es una tarea fácil que promueve aprendizaje significativo y relevante". La investigación educativa ha demostrado que el diseño de materiales innovadores requiere de un proceso de formación del profesorado (Rowel \& Ebbers, 2004; Krajcik et al., 2008). Sabemos que son múltiples las dificultades que el profesorado encuentra cuando elabora materiales. Es preciso por tanto apoyar a los equipos docentes aportando materiales didácticos experimentados en la práctica que sirvan de ayuda para diseñar, desarrollar y evaluar sus propias propuestas educativas (Cañal et al., 2005). Esta estrategia didáctica, que debe integrarse en la formación inicial y permanente del profesorado, estimula tanto el desarrollo profesional docente como el aprendizaje significativo al estar contextualizada en el medio del alumnado (Mckenney \& Voogt, 2012).

Seguidamente abordamos la última pregunta de investigación, correspondiente a la tercera categoría: ¿En qué proporción condicionan los materiales curriculares la forma de enseñar? Existe un claro consenso entre el profesorado a la hora de enjuiciar positivamente el papel de los materiales de elaboración propia de cara a su propia formación y su influencia efectiva en los procesos de enseñanza, a diferencia del libro de texto.

Por su parte, la realización de los estudios de casos ha permitido un doble análisis que se revela de especial utilidad para enjuiciar la influencia de los materiales en la enseñanza. De esta forma se han podido cruzar los datos emanados del análisis previo de la estructura didáctica de las propuestas a partir del Índice de Calidad Didáctica del Material (ICDM) con las evidencias obtenidas tras la realización de los estudios de casos, permitiendo comprender cómo estos procesos operan, sin la pretensión de establecer relaciones de causalidad generalizables. En este sentido, en el caso 1 donde se obtiene un ICDM bajo, se observa que gran parte de las decisiones curriculares han sido adoptadas por el autor del manual, relegando el rol de la docente a posibles modificaciones ocasionales para recoger las ideas e intereses del alumnado. Este cambio suele provocar conflicto con la lógica del material, provocando incertidumbre docente, familiar y escolar. No obstante, en el caso 2 -donde se aprecia un alto ICDM- la profesora, como diseñadora del material, adapta la propuesta didáctica del proyecto de trabajo al 
entorno y a los intereses del alumnado sin dependencia externa significativa. Cualquier modificación de la propuesta didáctica que promueva puede redundar en un incremento de la satisfacción de docente, de los padres y del propio alumnado.

Finalmente, observamos que lo verdaderamente importante no es cambiar unos materiales por otros: manuales por materiales hechos por docente o viceversa. Lo fundamental radica en potenciar la evolución de las creencias, los principios pedagógicos que la sustentan y el cambio de la práctica docente hacia la mejora educativa. En esta línea sería recomendable continuar con investigaciones, basadas en estudios de casos, que indaguen acerca del diseño, el desarrollo y la evaluación del currículum presentado en los materiales curriculares.

\section{Agradecimientos}

Este artículo se enmarca dentro del Proyecto de Investigación de Excelencia: ¿Cómo se realiza la enseñanza sobre la realidad social y natural en las aulas de Educación Infantil y Primaria de Andalucía? Estudio de las estrategias didácticas y propuestas de mejora. SEJ-5219 (2010-2014). Y del Proyecto I+D: ¿Cómo mejorar la enseñanza elemental sobre el medio?: análisis del currículo, los materiales y la práctica docente. EDU2009-12760EDUC (2009-2012).

Agradecemos la colaboración prestada por los Centros de Educación Infantil y Primaria Virgen del Carmen (Punta Umbría, Huelva) y El Puntal (Bellavista, Huelva) y muy especialmente a las maestras participantes.

\section{Referencias}

Adelman, N., Panton, K., Eagle, W., \& Hargreaves, A. (2003). Una carrera contra el reloj. Tiempo para la enseñanza y el aprendizaje en la reforma escolar. Madrid: Akal.

Apple, M. (1986). Teachers and Texts: A Political Economy of Class and Gender Relations in Education. London: Routledge.

Area, M. (1987). Medios de enseñanza y toma de decisiones del profesor. Un estudio cualitativo de casos. Unpublished Doctoral Thesis, Universidad de La Laguna (España). 
Arias, A.Mª Bismack, A., Davis, E., \& Palincsar, A. (2016). Interacting with a Suite of Educative Features: Elementary Science Teachers' Use of Educative Curriculum Materials. Journal of Research in Science Teaching, 53(3), 422-449. https://doi.org/10.1002/tea.21250

Atienza, E., \& Van Dijk, T. (2010). Identidad social e ideología en libros de texto españoles de Ciencias Sociales. Revista de Educación, 353, 67-106.

Bardin, L. (1996). Análisis de contenido (2a Ed.). Madrid: Akal.

Bayona, B. (2009). Reflexiones y propuestas sobre la política de gratuidad de los libros de texto en España. Asociación Nacional de Editores de Libros y Materiales de Enseñanza. Available at: http://www.anele.org/pdf/0902reflexionesypropuestas.pdf

Campagno, L., Castillo, S., \& Ferrero, S. (2009). El lugar del libro de texto para la enseñanza de las ciencias sociales en el tercer ciclo de E.G.B., en contextos sociales adversos. Conference paper delivered at Cuarto Congreso Nacional y Segundo Internacional de Investigación Educativa. Universidad Nacional del Comahue, Facultad de Ciencias de la Educación, Rio Negro Argentina, 21, 22 y 23 de octubre de 2009. Available at: http://trabajodecampojuegaalwiki.wikispaces.com/file/view/Libros+de+texto.pdf

Cañal, P., Pozuelos, F.J., \& Travé, G. (2005). Proyecto curricular Investigando nuestro mundo (pp. 6-12). Sevilla: Díada.

Cañal, P., Travé, G., \& Pozuelos, F.J. (2011). Análisis de obstáculos y dificultades de profesores y estudiantes en la utilización de enfoques de investigación escolar. Investigación en la escuela, 73, 5-26.

Carvalho, G., Silva, R., \& Clément, P. (2007). Historical analysis of Portuguese primary school textbooks (1920-2005) on the topic of digestion. International Journal of Science Education, 29(2), 173-193. https://doi.org/10.1080/09500690600739340

Charalambous, C., \& Hill, H. (2012). Teacher Knowledge, Curriculum Materials, and Quality of Instruction: Unpacking a Complex Relationship. Journal of Curriculum Studies, 44(4), 443-466. https://doi.org/10.1080/00220272.2011.650215

Chong, I. (2016). Pedagogical Design Capacity and Underlying Knowledge Base of Curriculum Materials Use of a Hong Kong English Teacher. English Language Teaching, 9(5), 85-97. https://doi.org/10.5539/elt.v9n5p85

Fernández Reiris, A. (2003). La función del libro de texto en el aula. Hegemonía y control del curriculum. Unpublished doctoral thesis, Universidad de Valencia (España). 
Figg, C., \& Jaipal-Jamani, K. (2011). Exploring Teacher Knowledge and Actions Supporting Technology-Enhanced Teaching in Elementary Schools: Two Approaches by Pre-Service Teachers. Australasian Journal of Educational Technology, 27(7), 1227-1246. https://doi.org/10.14742/ajet.914

Forbes, C., \& Davis, E. (2010). Curriculum design for inquiry: Preservice elementary teachers' mobilization and adaptation of science curriculum materials. Journal of Research in Science Teaching, 47(7), 820-839. https://doi.org/10.1002/tea.20379

García-Prieto, F.J., López, F.J., \& Correa, C. (2013). ¿Qué quiero ser de mayor? Trabajando las profesiones en el aula de infantil. Cuadernos de Pedagogía, 432, 58-60.

Green, R.A. (2014). The Delphi Technique in Educational Research (pp. 1-8). Thousand Oaks, The United States: SAGE Open. https://doi.org/10.1177/2158244014529773

Grossman, P., \& Thompson, C. (2008). Learning from Curriculum Materials: Scaffolds for New Teachers?. Teaching and Teacher Education: An International Journal of Research and Studies, 24(8), 20142026. https://doi.org/10.1016/j.tate.2008.05.002

Güemes, R.Ma . (2001). Algunas investigaciones en torno al uso de los libros de texto en las aulas. Primeras Noticias. Comunicación y pedagogía: Nuevas tecnologías y recursos didácticos, 20(175), 76-83.

Hargreaves, A. (1996). Profesorado, cultura y posmodernidad. Cambian los tiempos, cambia el profesorado. Madrid: Morata.

Henning, H., Hlawatsch, S., \& Lucken, M. (2007). Enactment of a Geoscience Curriculum by Using Innovative Curriculum Materials: An Exploratory Case Study. Journal of Geography Education, 35(4), 286-306.

Hernández, A. (2012). ¿Cómo tratan los libros de texto de bachillerato la crisis económica? Investigación en la Escuela, 76, 51-64.

Issitt, J. (2004). Reflections on the study of textbooks. History of Education, 33(6), 683-697. https://doi.org/10.1080/0046760042000277834

Kasim, Y. (2008). A case study on the use of materials by classroom teachers. Educational Sciences: Theory and Practice, 8(1), 305-322.

Krajcik, J., McNeill, K., \& Reiser, B. (2008). Learning-Goals-Driven Design Model: Developing Curriculum Materials that Align with National Standards and Incorporate Project-Based Pedagogy. Science Education, 92(1), 1-32. https://doi.org/10.1002/sce.20240 
Loeb, H., Knapp, M.S., \& Elfers, A.M. (2008). Teachers' response to standards-based reform: Probing reform assumptions in Washington State. Education Policy Analysis Archives, 16(8), 1-32. Available at: http://epaa.asu.edu/epaa/v16n8 https://doi.org/10.14507/epaa.v16n9.2008

López Hernández, A. (2007). Libros de texto y profesionalidad docente, Avances en Supervisión Educativa. Revista de la Asociación de Inspectores de Educación de España, 6, 1,13. Available at: http://www.adide.org/revista/index.php/ase/article/view/282/244

Maestro, P. (2002). Libros escolares y currículum. Del reinado de los libros de texto a las nuevas alternativas del libro escolar. Revista de Teoría y Didáctica de las Ciencias Sociales, 7, 25-52.

Martínez-Rizo, F. (2012). Procedimientos para el estudio de las prácticas docentes. Revisión de la literatura. Relieve, 18(1), art.1. Available at: http://www.uv.es/RELIEVE/v18n1/RELIEVEv18n1 1.htm

Mckenney, S., \& Voogt, J. (2012). Teacher Design of Technology for Emergent Literacy: An Explorative Feasibility Study. Australasian Journal of Early Childhood, 37(1), 4-12.

McKernan, J. (1991). Curriculum Action Research: a Handbook of Methods and Resources for the Reflective Practitioner. London: Kogan Page Ltd.

Morcillo, V., \& Romero, D. (2013). ¡Estar en forma es genial!. Cuadernos de pedagogía, 432, 61-63.

Moulton, J. (1997). How do teachers use textbooks? A review of the research literature. Health and Human Resources Analysis for Africa Project. Technical Paper 74. Available at: http://textbookuse.pbworks.com/f/74textbooks.pdf

Paredes, J. (1999). Análisis etnográfico de los usos de recursos y materiales didácticos en educación primaria. Estudios de los casos de dos centros. Tesis doctoral inédita, Universidad Complutense de Madrid (España).

Peiró-Velert, C., Molina-Alventosa, P., Kirk, D., \& Devís-Devís, J. (2015). The Uses of Printed Curriculum Materials by Teachers during Instruction and the Social Construction of Pedagogic Discourse in Physical Education. Journal of Teaching in Physical Education, 34(1), 18-35. https://doi.org/10.1123/jtpe.2012-0157

Pérez Gómez, Á.I., \& Gimeno, J. (1994). Evaluación de un proceso de innovación educativa. Sevilla: Junta de Andalucía.

Pingel, F. (2010). Guide UNESCO pour l'analyse et révisión des manuels scolaires. Francia: UNESCO.

Pinto, L. (2007). Textbook publishing, textbooks, and democracy. A case study. Journal of Thought, 42(1-2), 99-121.

Pozuelos, F.J., Travé, G., \& Cañal, P. (2007). Acerca de cómo el profesorado de primaria concibe y experimenta los procesos de investigación escolar. Revista de Educación, 344, 403-423. 
Pozuelos, F.J., Travé, G., \& Cañal, P. (2010). Inquiry-based teaching: teachers’ conceptions, impediments and support. Teaching Education, 21(2), 131-142. https://doi.org/10.1080/10476210903494507

Reininger, J. (2010). My text: An alternative to traditional textbook. Computers in Human Behavior, 26, 119-121. https://doi.org/10.1016/j.chb.2009.09.004

Rodríguez, J. (2000). Os materiais curriculares impresos e a reforma educativa en Galicia. Unpublished doctoral thesis, Universidad de Santiago de Compostela (España).

Rowel, P., \& Ebbers, M. (2004). School Science Constrained: Print Experiences in Two Elementary Classrooms. Teaching \& Teacher Education: An International Journal of Research and Studies, 20(3), 217-230. https://doi.org/10.1016/j.tate.2004.02.006

Simons, H. (2011). El estudio de caso: Teoría y práctica. Madrid: Morata.

Sosniak, L., \& Stodolsky, S. (1993). Teachers and textbooks: Materials use for fourth-grade classrooms. The Elementary School Journal, 93(3), 249-275. https://doi.org/10.1086/461725

Soto, F. (2006). El libro de texto y la biblioteca escolar. La escuela del pasado y la del futuro. Revista TK, 18, 27-39.

Stenhouse, L. (1987). La investigación como base de la enseñanza. Madrid: Morata.

Su, Y.S. (2007). Ideological Representations of Taiwan's History: An Analysis of Elementary Social Studies Textbooks, 1978-1995. Curriculum Inquiry, 37(3), 205-237. https://doi.org/10.1111/j.1467873X.2007.00383.x

Travé, G., \& Pozuelos, F.J. (2008). Consideraciones didácticas acerca de las líneas de investigación en materiales curriculares. A modo de presentación. Investigación en la Escuela, 65, 3-10.

Travé, G., Pozuelos, F.J., \& Cañal, P. (2006). Cómo enseñar investigando análisis de las percepciones de tres equipos docentes con diferentes grados de desarrollo profesional. Revista Iberoamericana de Educación, 39(5), 1-24. Available at: http://rieoei.org/1366.htm

Travé, G., Pozuelos, F.J., \& Cañal, P. (2016). Diseño de la investigación. En P. Cañal, G. Travé, F.J. Pozuelos, A. Criado y A. García (Coords), La enseñanza sobre el medio natural y social. Investigación y experiencias (pp. 23-34). Sevilla: Díada.

Travé, G., Pozuelos, F.J., Cañal, P., \& Rodríguez, F.P. (2016). Validación de un instrumento de análisis de materiales (AMADE). In P. Cañal, G. Travé \& F.J. Pozuelos et al. (Coords.), La enseñanza sobre el Medio Natural y Social, Investigación y experiencias (pp. 97-114). Sevilla: Díada. 
Varela, J. (2008). El libro de texto ante la incorporación de las TIC a la enseñanza. Available at: http://federacioneditores.org/img/documentos/Los TIC enEnsenanza.pdf

Vargas, J.C., \& Chavarría, A. (2011). El libro de texto: Los profesores de hoy. Ensayos Pedagógicos, 1(1), 133-143.

Winzenried, A., Dalgarno, B., \& Tinkler, J. (2010). The Interactive Whiteboard: A Transitional Technology Supporting Diverse Teaching Practices. Australasian Journal of Educational Technology, 26(special issue 4), 534-552. https://doi.org/10.14742/ajet.1071

Yelas, J., \& Engels, P. (2010). Project ACTIVate: Innovations from New Zealand. Australasian Journal of Educational Technology, 26(4), 432-446. https://doi.org/10.14742/ajet.1063

Zahorik, J. (1991). Teaching style and textbooks. Teaching and Teacher Education, 7(2), 185-196. https://doi.org/10.1016/0742-051X(91)90026-L

Zembylas, M. (2004). Emotion Metaphors and Emotional Labor in Science Teaching. Science Education, 88(3), 301-324. https://doi.org/10.1002/sce.10116

Zenobi, V. (2012). Los profesores de Geografía, la innovación de la enseñanza y su profesionalización: el lugar de los materiales curriculares. Conference paper presented at I Encuentro Iberoamericano de Investigación en Didáctica de las Ciencias Sociales. Panel La Enseñanza y el Aprendizaje de la Geografía y la Historia. Universidad de Antioquia, Medellín, Colombia, 6 y 7 de diciembre de 2012.

\section{Anexo}

\begin{tabular}{|c|c|c|c|c|c|c|c|c|c|c|c|c|c|c|c|c|c|c|c|}
\hline & 2 & 3 & 5 & 7 & 8 & 9 & 14 & & 23 & $25 a$ & $25 b$ & $25 c$ & $25 d$ & 30 & $31 a$ & $31 \mathrm{~b}$ & 31c & 31d & $31 \mathrm{e}$ \\
\hline & & & 5.9 & 2.7 & 1.2 & 18.8 & 0.9 & 16.7 & 10.5 & & 12.9 & 11.6 & & 2.9 & & & 5.0 & 4.6 & \\
\hline & & & & 21.3 & & & & & & & & & & & & & 48.4 & & \\
\hline & & & & & 7.2 & 49 & 9.2 & .2 & 40.2 & & & .6 & .3 & 29.8 & & & 3.4 & & \\
\hline & & & & .2 & & & 39.4 & & & & & & & & & & & & \\
\hline & & & & & & & & 3 & & & & & & & & & & & 1 \\
\hline & & & & 5.2 & & & .5 & 3.4 & 58.6 & & 5.8 & 33.0 & ) & 9.6 & & .7 & 5.5 & & 3. \\
\hline & & & & 3.08 & 3.45 & 2.57 & & & 2.72 & 2.29 & 2.32 & 2.29 & 2.17 & 2.85 & & 2.21 & 2.48 & 2.76 & \\
\hline & .070 & & .611 & .818 & .662 & 1.076 & .682 & .767 & .939 & .813 & .794 & .768 & .816 & .737 & & .686 & .703 & .758 & \\
\hline rdido & 0.5 & 0.5 & 1.0 & 0.8 & 0.2 & 2 & 0.2 & 0.5 & 1.2 & 1.4 & 1.5 & 1.4 & 1.6 & 0.6 & 1.3 & 1.0 & 1.2 & 1.2 & \\
\hline
\end{tabular}




\begin{tabular}{|c|c|c|c|c|c|c|c|c|c|c|c|c|c|c|c|c|}
\hline & 32 & 41 & 43 & 44 & 45 & $46 a$ & $46 b$ & $46 c$ & $46 d$ & $46 \mathrm{e}$ & $46 f$ & 49 & $50 a$ & $50 \mathrm{~b}$ & $50 c$ & $50 \mathrm{~d}$ \\
\hline R1 & 1.2 & 31.1 & 0.5 & 5.1 & 4.2 & 3.8 & 1.6 & 8.3 & 3.1 & 4.6 & 0.2 & 12.4 & 0.6 & 0.6 & 0.8 & 0.8 \\
\hline R2 & 20.0 & 42.3 & 15.6 & 31.2 & 43.9 & 22.8 & 19.2 & 28.6 & 20 & 34.4 & 2.3 & 61.6 & 10.5 & 10.3 & 8.8 & 12.3 \\
\hline R1+R2 & 1.2 & 73.4 & 16.1 & 36.3 & 48.1 & 26.6 & 20.8 & 36.8 & 23.1 & 39.0 & 2.5 & 74.0 & 11.1 & 10.9 & 9.6 & 13.1 \\
\hline R3 & 7.2 & 19.7 & 51.0 & 45.0 & 42.1 & 43.1 & 51.9 & 42.2 & 44.5 & 41.3 & 3.6 & 22.1 & 49.9 & 46.0 & 41.6 & 42.2 \\
\hline R4 & 8.3 & 5.7 & 32.8 & 18.0 & 8.6 & 29 & 26.4 & 19.6 & 30.7 & 18 & 5.0 & 3.0 & 38.0 & 42.3 & 47.5 & 43.6 \\
\hline & 5.5 & 25.4 & 82.8 & 63.0 & 50.7 & 72.1 & 78.3 & 61.8 & 75.2 & 59.3 & 8.6 & 25.1 & 87.9 & 88.3 & 89.1 & 85.8 \\
\hline & 3.09 & 2.00 & 3.16 & 2.36 & 2.56 & 2.98 & 3.04 & 2.74 & 3.04 & 2.74 & 3.20 & 2.16 & 3.27 & 3.31 & 3.38 & 3.30 \\
\hline $\begin{array}{l}\text { DESV.TIPI } \\
\text { CA }\end{array}$ & 1.01 & .863 & .691 & .885 & .711 & .825 & .724 & .871 & .801 & .809 & .841 & .667 & .666 & .677 & .680 & .713 \\
\hline Perdidos & 3.2 & 1.3 & 0.1 & 0.8 & 1.3 & 1.3 & 0.8 & 1.3 & 1.6 & 1.7 & 88.9 & 0.8 & 0.9 & 0.8 & 1.3 & 1.2 \\
\hline
\end{tabular}

Tabla 2. Datos de resultados generales de los ítems del cuestionario

Intangible Capital, 2017 (www.intangiblecapital.org)

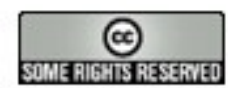

Article's contents are provided on an Attribution-Non Commercial 3.0 Creative commons license. Readers are allowed to copy, distribute and communicate article's contents, provided the author's and Intangible Capital's names are included. It must not be used for commercial purposes. To see the complete license contents, please visit http://creativecommons.org/licenses/by-nc/3.0/. 